\title{
Ethanol Transportation Backgrounder
}

\section{Expansion of U.S. Corn-based Ethanol \\ from the Agricultural Transportation Perspective}

U.S. Department of

Agriculture

Agricultural Marketing

Service

Transportation and

Marketing Programs

Transportation Services

Branch

September 2007

\section{CONTENTS}

Introduction 1

Ethanol Supply

and Demand

Overview

Ethanol

Transportation

Outlook:

Current and

Projected

Infrastructure

Issues

Government

Biofuel

Activities

Appendix I

Scenario

Tables 18

Appendix II

Illustrations

22

Resources and Links 26

Contact Us 29
The Ethanol Transportation Backgrounder is an overview of transportation issues facing a rapidly expanding U.S. ethanol industry in the context of the U.S. corn market - currently the main source of ethanol production in the United States. The aim of the report is to present a frame of reference as the ethanol industry continues to grow and additional transportation benchmarks and indicators develop by providing analysis of transportation requirements for corn-based ethanol and its impact on grain transportation.

\section{SUMMARY}

For the first 6 months of 2007, U.S. ethanol production totaled nearly 3 billion gallons-32 percent higher than the same period last year. As of August 29, there were 128 ethanol plants with annual production capacity totaling 6.78 billion gallons, and an additional 85 plants were under construction. U.S. ethanol production capacity is expanding rapidly and is currently expected to exceed 13 billion gallons per year by early 2009 , if not sooner.

Ethanol demand has increased corn prices and led to expanded corn production, which is affecting grain transportation as corn use shifts from exports and feed use to ethanol production.

Most ethanol is currently produced in the Nation's heartland, but 80 percent of the U.S. population (and therefore implied ethanol demand) lives along its coastlines. Transportation factors to consider as ethanol production continues to expand in the Nation's heartland include:

- The capacity of the Nation's transportation system to move ethanol, feedstock, and co-products produced from ethanol.

- The availability of corn close to ethanol plants ( 50 miles).

- The location of feedlots relative to ethanol producing areas.

Ethanol production capacity expansion is occurring faster than originally anticipated. In May, USDA issued a report analyzing the effects of an expansion in biofuel demand on U.S. agriculture. The analysis focused on two ethanol expansion scenarios in relation to the Baseline long-term projections issued in February 2007. Under Scenario 1, U.S. ethanol production increases to 15 billion gallons per year (bgy) by 2016. Under Scenario 2, U.S. ethanol production increases to 20 bgy by 2016. AMS applied its modal share analysis to the three USDA scenarios: baseline (February 2007 long-term projections) and the two scenarios described above to evaluate the impact of ethanol production expansion on grain transportation. The 5-year 2000-2004 modal share rates were assumed to stay constant over the projected period.

- Transportation impacts vary for each scenario and transportation mode due in part to modal share differences.

- Rail and barge demand could decrease if corn exports decrease, but in the short-term increased ethanol and DDGS shipments could offset decreases in rail grain shipments.

- Truck demand increases under all scenarios.

In 2005, rail was the primary transportation mode for ethanol, shipping 60 percent of ethanol production or approximately 2.9 billion gallons of ethanol. Trucks shipped 30 percent and barges 10 percent.

The growth of ethanol production and the construction and expansion of new plants have not been hampered by logistical concerns. Railroads have kept up with ethanol growth in 2006. As ethanol production grew by 26 percent in one year, railroads' shipments of alcohols (most of which is ethanol) increased by 28 percent.

Rail freight is forecast to increase from 1,879 million tons in 2002 to 3,525 million tons by 2035 , an increase of nearly 88 percent-before ethanol production expansion.

Truck freight is forecast to almost double from 2002 to 2020 , while driver shortages are projected to reach 219,000 by 2015 -before ethanol production expansion. In 2004, there were 1.3 million long-haul heavy-duty truck drivers. 


\section{INTRODUCTION}

On August 8, 2005, President Bush signed the Energy Policy Act of 2005 (EPAct 2005) into law. The comprehensive energy legislation established a nationwide renewable fuels standard (RFS) that was to start at 4 billion gallons in 2006 and increase to 7.5 billion gallons by 2012 (Table 1). Under the RFS, an increasing percentage of the national fuel supply is to be provided by renewable, domestic fuels, including ethanol and biodiesel. The key objectives are to reduce consumer fuel prices, increase energy security, improve environmental quality, and stimulate growth in rural America.

EPAct 2005, rising petroleum prices, and the switch from MTBE to ethanol as a gasoline oxygenator are widely credited for the expansion in ethanol production capacity. Ethanol is denatured alcohol used as a gasoline additive for its oxygen and octane content and is currently blended into almost half of US gasoline at a maximum 10 percent. ${ }^{1}$ The U.S. ethanol industry surpassed the RFS in 2006, when 4.9 billion gallons of ethanol were produced and used. Expanded production capacity currently under construction is expected to double annual ethanol production capacity to 12.9 billion

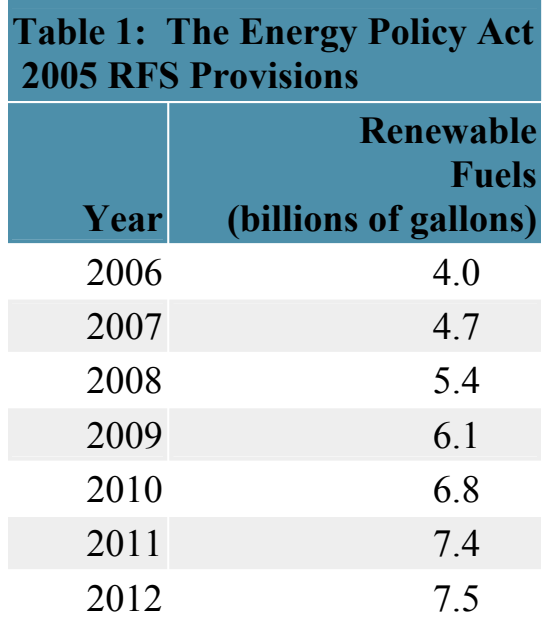
gallons by the end of 2009, if not sooner. ${ }^{2}$

The President announced the Advanced Energy Initiative in the 2006 State of the Union Address. The Advanced Energy Initiative focuses on increasing research and development to encourage technological breakthroughs in the transportation and power sectors that will diversify our resource portfolio.

In his 2007 State of the Union Address, President Bush announced his goal to expand consumption of alternative fuels (including biofuels) to 35 billion gallons in 2017 ("20 in 10" 20 percent of projected gasoline use is to be replaced by renewable or alternative energy sources, as well as improved energy efficiency). Because cellulosic ethanol is not yet a current market reality, this report focuses on transportation requirements for corn-based ethanol and its impact on the grain transportation based on official USDA projections.

\footnotetext{
${ }^{1}$ Ethanol producers are required by the U.S. Drug Enforcement Administration (DEA) to denature the 200-proof ethanol before it is shipped. DEA has specific guidelines for the process that makes the ethyl alcohol into a fuel grade ethanol-E95.

${ }^{2}$ Renewable Fuels Association - capacity as of August 1, 2007, www.rfaethanol.org.
} 


\section{USDA Analysis of Expanded Ethanol Use on U.S. Agriculture}

The rapidly expanding ethanol production capacity and Congressional inquiry prompted analysis from USDA in addition to the long-term baseline projections issued in February. ${ }^{3}$ In May, USDA issued a special report analyzing the impact of expanding current corn starch-based biofuel production on agriculture under two alternative scenarios. ${ }^{4}$ The report examines two scenarios for crop years 2007-16 using an econometric model of the U.S. agricultural sector. Under Scenario 1, annual domestic ethanol production increases to 15 billion gallons (bgy) by 2016 - 3 bgy higher than assumed in the baseline projections. Under Scenario 2, annual domestic ethanol production increases to 20 bgy by 2016 (figure 1). The increase in ethanol production is assumed to use corn as the feedstock.

USDA projects corn production in the baseline and the 15-bgy scenarios to increase from 13.05 billion bushels (bbu) in 2007 to 14.1 and $14.5 \mathrm{bbu}$ in 2016, respectively. Under the 20-bgy scenario, corn production is expected to increase to 15.5 bbu by 2016 in (Appendix I, tables 1-3). Producers are expected to respond to the implied higher corn prices by shifting land from the production of soybeans into corn. Prices for minor feed grains are assumed to increase under both scenarios, thus increasing their estimated production slightly under both scenarios. The area planted to wheat, upland cotton, and rice would decline somewhat under both scenarios, as producers expand the area planted to feed grains.

USDA analysis projects that total area planted would increase under both scenarios, due to the overall increase in profitability in the crop sector. USDA analysis shows that total area planted would increase by an average of 0.9 and 1.9 million acres, for Scenarios 1 and 2, respectively. Thus, the area required to accommodate the expansion in ethanol production is composed of area planted to competing crops and from an overall expansion of area planted.

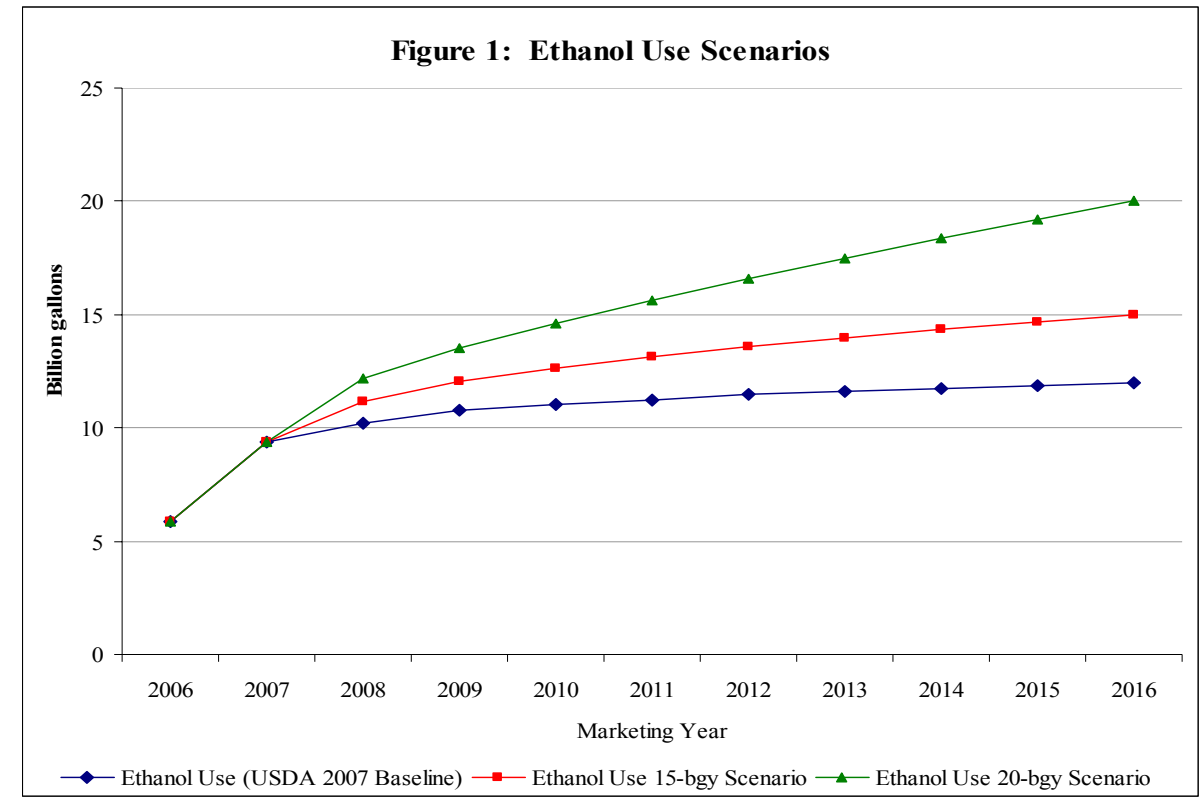

\footnotetext{
${ }^{3}$ USDA Agricultural Projections to 2016, February 2007. http://www.usda.gov/oce/commodity/ag baseline.htm

${ }^{4}$ An Analysis of the Effects of an Expansion in Biofuel Demand on U.S. Agriculture May 2007. http://www.usda.gov/oce/
} 


\section{Transportation Implications}

As corn production increases, transportation demand would normally be expected to increase. However, corn use for fuel is likely to have a mixed impact on rail, truck, and barge transportation. For example, trucks are used to ship most of the corn used by ethanol plants. But, the newer and bigger ethanol plants may also use rail for inbound corn shipments.

The variability in modal share of corn transportation is another contributing factor to the mixed impact on rail, barge, and truck sectors. Analysis of the average modal share for the five years (2000-2004) showed that railroads ship approximately 31 percent of corn to export locations and 30 percent to domestic locations; barges - 68 percent to export and 2 percent to domestic locations; and trucks -2 percent to export locations and 67 percent to domestic locations. $^{5}$

\begin{tabular}{|l|r|r|r|}
\hline \multicolumn{1}{|c|}{ Corn Modal Share (2000-2004 average), percent } \\
\hline & Rail & Barge & Truck \\
\hline Exports & 31 & 68 & 2 \\
\hline Domestic & 30 & 2 & 67 \\
\hline
\end{tabular}

Transportation requirements for ethanol would increase proportionately as production increases. The necessary investment and growth in the biofuel market to reach the suggested long-term targets will depend in part on finding cost-effective, efficient, and safe transportation solutions.

Railroads, trucks, and barges transport most ethanol today from production or import locations to locations where it is blended with gasoline at or near the point of retail distribution (Appendix II). To sustain the market growth needed to meet current suggested targets, or to reach either of the scenarios analyzed by USDA, infrastructure must be developed for transporting biofuel and co-products to market.

\footnotetext{
${ }^{5}$ Transportation of U.S. Grains: a Modal Share Analysis, 1978-2004. (Total may not add due to rounding). http://www.ams.usda.gov/tmd/TSB/Modal_Share.pdf
} 


\section{ETHANOL SUPPLY AND DEMAND OVERVIEW}

\section{Ethanol Supply}

For the first 6 months of 2007, U.S. ethanol production totaled nearly 3 billion gallons - 32 percent higher than the same period last year. As of August 29, 128 ethanol plants with a total annual capacity of 6.78 billion gallons were operating, and an additional 85 plants were under construction or expansion. U.S. ethanol production capacity is expanding rapidly and is currently expected to exceed 13 billion gallons by early 2009, if not sooner.

Ethanol production is a function of several factors, including feedstock availability, profitability, tax incentives, and technological advances. Currently, nearly all ethanol produced in the United States uses corn as its feedstock. In theory, the economics of dry feedstock vs. finished liquid fuel transportation favor the location of the ethanol plants in the Corn belt, where the feedstock is plentiful and less expensive. Ethanol is now being produced in more than

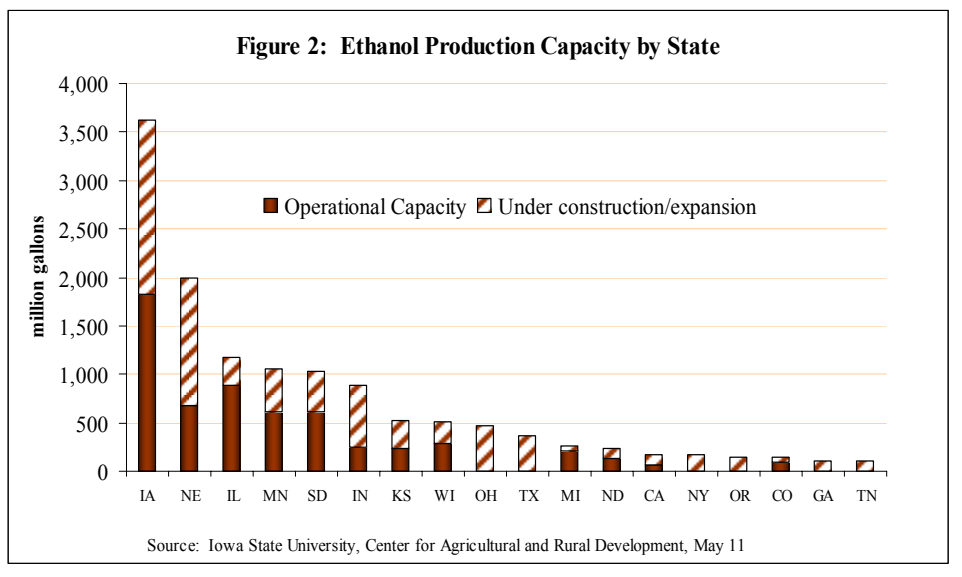
20 states, but about 90 percent of production capacity is concentrated in an 8-state area that encompasses Iowa, Nebraska, Illinois, Minnesota, South Dakota, Indiana, Kansas, and Wisconsin (Figure 2).

Most ethanol is currently produced in the Nation's heartland, but 80 percent of the U.S. population (and therefore implied ethanol demand) lives along its coastlines. Transportation factors to consider as ethanol production continues to expand in the Nation's heartland include:

- The capacity of the Nation's transportation system to move ethanol, feedstock, and coproducts produced from ethanol.

- The availability of corn close to ethanol plants ( $\sim 50$ miles).

- The location of feedlots for use of co-products relative to ethanol producing areas.

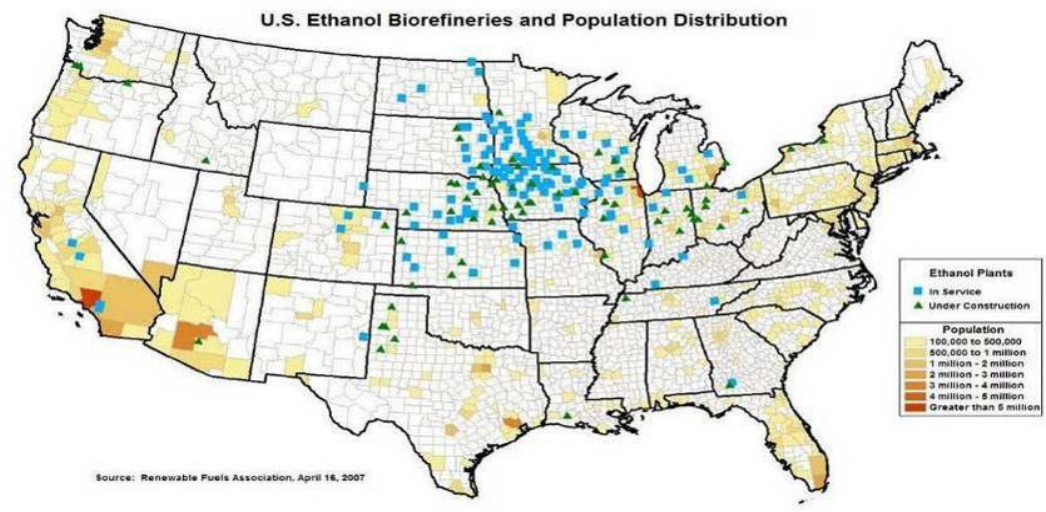




\section{Ethanol Demand}

Ethanol is blended to a maximum ratio of 10 percent ethanol and 90 percent gasoline (E10). Automobiles, as currently manufactured for the U.S. market, are capable of running on E10. The potential demand for ethanol if the United States consumes E10 nationwide could be approximately 14 billion gallons (Table 2). Efforts are underway to examine the use of blends beyond 10 percent in standard automobiles, which could increase potential demand of ethanol and avoid hitting the "blend wall" of an E10 ceiling.

Some regions of the Nation have expanded ethanol use - for example, the California Air Resources Board recently approved the increased use of ethanol in gasoline from the current 5.7 percent volume limit to 10 percent. California's legislature is expected to pass the new rule in the fall of 2007 and the State may start blending ethanol at higher levels as early as 2008. This would increase total ethanol consumption in California to approximately 1.6 billion gallons - about 23 percent of the current ethanol production capacity. Legislatures in southeastern States are also considering increasing ethanol-blending requirements. This adds to the uncertainty of ethanol demand in terms of volumes, timing, and geographic location.

U.S. automakers have corporate average fuel economy (CAFE) standard incentives to increase the production and sale of flex-fuel vehicles (FFV's) that are capable of using fuel that contains 85 percent ethanol and 15 percent gasoline (E85). It is estimated that today there are over 6 million FFV's on the road in the United States (Appendix II). Automakers have pledged to increase that number to 10 million vehicles by 2010 and make FFV's 50 percent of their production line by 2015 .

As the number of FFV's increases, the retail availability of E85 gas stations and fuel is expected to follow. Around 1,166 gas stationsless than 1 percent of 121,446 gas stations in the United States in 2002 - currently sell E85 gas, concentrated in the Midwest.

\begin{tabular}{|c|c|c|c|}
\hline $\begin{array}{r}\text { Table } 2 \\
\text { (In million gallon }\end{array}$ & $\begin{array}{r}\text { otential Et } \\
\text { ased on } 10 \% \text { b } \\
\text { Consumpti }\end{array}$ & $\begin{array}{l}\text { ol Volu } \\
\text { f } 2004 \mathrm{M}\end{array}$ & $\begin{array}{l}\text { mes } \\
\text { otor Gasoline }\end{array}$ \\
\hline & thanol Cons & tion & \\
\hline State & Potential & 2005 & $\begin{array}{r}\text { Potential \% } \\
\text { Increase } \\
\end{array}$ \\
\hline Alabama & 261 & 41 & 533 \\
\hline Alaska & 29 & 6 & 396 \\
\hline Arizona & 274 & 14 & 1,830 \\
\hline Arkansas & 145 & & \\
\hline California & 1,579 & 918 & 72 \\
\hline Colorado & 213 & 102 & 109 \\
\hline Connecticut & 184 & 162 & 14 \\
\hline Delaware & 42 & & \\
\hline Dist. of Col. & 15 & & \\
\hline Florida & 847 & & \\
\hline Georgia & 507 & & \\
\hline Hawaii & 45 & & \\
\hline \begin{tabular}{|l|} 
Idaho \\
\end{tabular} & 63 & & \\
\hline Illinois & 527 & 455 & 16 \\
\hline Indiana & 324 & 136 & 138 \\
\hline Iowa & 166 & 128 & 29 \\
\hline Kansas & 134 & 18 & 635 \\
\hline Kentucky & 232 & 77 & 202 \\
\hline Louisiana & 234 & 66 & 256 \\
\hline Maine & 71 & & \\
\hline Maryland & 267 & 0 & 90,774 \\
\hline Massachusetts & 287 & 10 & 2,867 \\
\hline Michigan & 500 & 195 & 156 \\
\hline Minnesota & 272 & 276 & \\
\hline Mississippi & 165 & & \\
\hline Missouri & 324 & 127 & 155 \\
\hline Montana & 50 & 1 & 3,407 \\
\hline Nebraska & 88 & 53 & 66 \\
\hline Nevada & 109 & 53 & 106 \\
\hline New Hampshire & 72 & & \\
\hline New Jersey & 436 & 7 & 6,386 \\
\hline New Mexico & 98 & 6 & 1,526 \\
\hline New York & 577 & 328 & 76 \\
\hline North Carolina & 443 & 116 & 280 \\
\hline North Dakota & 36 & 17 & 111 \\
\hline \begin{tabular}{|l} 
Ohio \\
\end{tabular} & 524 & 264 & 99 \\
\hline Oklahoma & 191 & & \\
\hline Oregon & 155 & 31 & 399 \\
\hline Pennsylvania & 523 & 100 & 421 \\
\hline Rhode Island & 38 & 10 & 301 \\
\hline South Carolina & 259 & & \\
\hline South Dakota & 44 & 27 & 60 \\
\hline Tennessee & 306 & & \\
\hline Texas & 1,158 & 29 & 3,890 \\
\hline Utah & 104 & 2 & 4,568 \\
\hline Vermont & 35 & & \\
\hline Virginia & 398 & 106 & 275 \\
\hline Washington & 270 & 25 & 972 \\
\hline West Virginia & 85 & 23 & 275 \\
\hline Wisconsin & 257 & 127 & 102 \\
\hline Wyoming & 33 & & \\
\hline United States & 13,997 & 4,059 & 245 \\
\hline
\end{tabular}

Source: DOE/EIA; Table F13a: Wood, Waste, and

Ethanol Consumption Estimates by Sector, 2005

http://www.eia.doe.gov/emeu/states/ seds updates.html 


\section{ETHANOL TRANSPORTATION OUTLOOK: \\ Current and Projected}

\section{Transportation Background}

Rapid expansion of the U.S. ethanol industry could have several implications for agricultural transportation, including increasing volumes of ethanol shipments and shifting grain and oilseed marketing patterns that could occur due to changes in production and use.

Transportation is typically the third highest expense to an ethanol producer-after feedstock and energy. Balancing transportation operating expenses with fixed infrastructure costs can be critical to sustained profitability for each ethanol plant. Storage needs for ethanol are also related to transportation needs - truck and rail have a faster turnaround and barges can haul larger quantities. For example, trucks offer more flexibility and responsiveness to move the product as the market dictates, reducing storage needs at the ethanol plant. But, barge may offer cost savings due to volumes moved. Other transportation requirements include inbound feedstock and outbound co-products. Corn is shipped to the plant as feedstock (mostly by truck) and distillers grains (dry distillers grains with solubles (DDGS) and wet distillers grains (WDGs)) are shipped by truck, rail, or barge.

For purposes of comparison, a large petroleum 2-barge unit tow hauls 2.52 million gallons (although ethanol is usually shipped in smaller, 630,000-gallon tanker barges), which is equivalent to about 80 railcars or 300 tanker trailers (table 3 and Appendix II). In 2005 , rail was the primary transportation

\begin{tabular}{|lrcr|}
\hline \multicolumn{4}{|c|}{ Table 3: CARGO CAPACITY COMPARISON } \\
\multicolumn{1}{|c}{ Capacity (units) } & Railcar & Barge & Truck \\
Grain (bushels) & 3,500 & 52,500 & 910 \\
Ethanol (gallons) & 29,400 & 630,000 & 8,000 \\
DDGS (tons) & 100 & 1,500 & 25 \\
\hline
\end{tabular}
mode for ethanol, shipping 60 percent of ethanol production-approximately 2.9 billion gallons of ethanol; followed by trucks - 30 percent, and barges - 10 percent (figure 3).

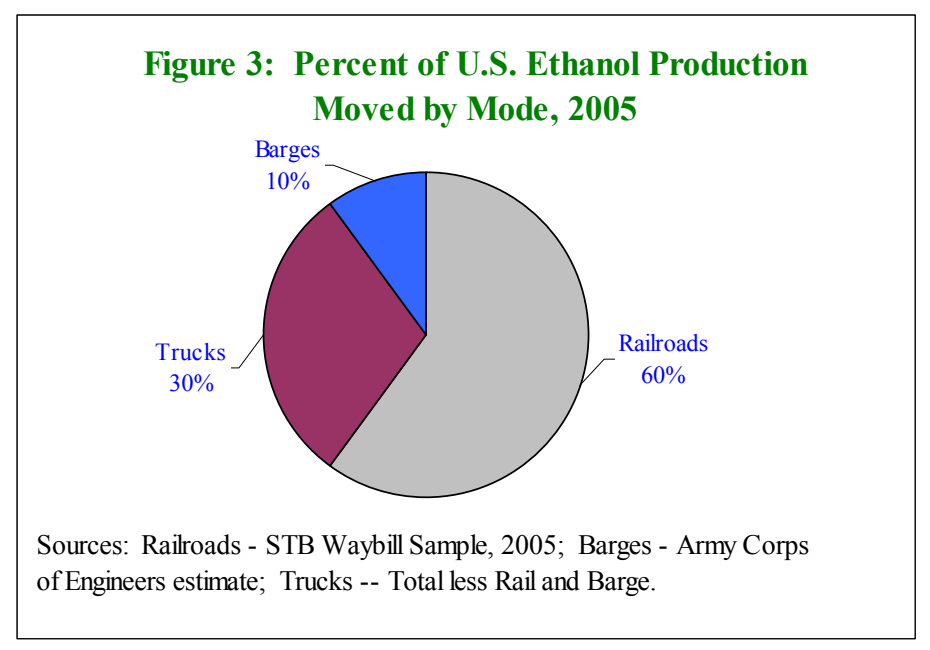


Ethanol transactions currently involve two types of marketing arrangements: 1) direct sales to customers and 2) movements to a strategic location. Both types of arrangements require transportation. Movement of the product can be arranged by the customer, supplier, or a third party - known in the petroleum industry as the marketer.

As the number of companies producing ethanol increases, the share of ethanol marketed by third parties - marketers - is expected to rise as well. The marketers ensure supply interruptions are kept to a minimum and are able to move large volumes by gathering production from several smaller ethanol plants into unit trains (trains consisting of 85-100 cars that stay together from origin to destination). The role of the regional (shortline) railroads has increased for the shorter movements of ethanol to intermediate rail terminals.

As ethanol volumes rise, the industry may start requiring quality control programs that ensure that shipments are not contaminated with other chemicals. Ethanol producers are expected to continue to rely on qualified ethanol marketers to efficiently distribute their products. Some railroads have instituted a Certificate of Authenticity program that certifies ethanol quality shipments on their railroad.

\section{Transportation Sensitivity to Demand and Distribution Changes}

All three modes used to transport ethanol-rail, barge, and truck - are at or near capacity. Total rail freight is forecast to increase from 1,879 million tons in 2002 to 3,525 million tons by 2035, an increase of nearly 88 percent. $^{6}$ Federal Highway Administration projects truck freight to almost double from 2002 to 2020, and driver shortages are projected to reach 219,000 by 2015 . In 2004, there were 1.3 million long-haul heavy-duty truck drivers. ${ }^{7}$ The lock and dam system on the inland waterways is aging.

The lack of excess transportation capacity increases the sensitivity of transportation to sudden changes in transportation demand and distribution patterns. Changes in these patterns brought on by rapidly increasing ethanol production could impact rail network performance, highway congestion, and barge traffic. For example, the increased sensitivity of transportation modes became evident in the aftermath of Hurricanes Katrina and Rita in 2005, when rail had insufficient capacity to transport displaced grain barge freight and trucks could not carry the grain economically for long distances.

To date, logistical concerns have not hampered ethanol production growth or the construction and expansion of new ethanol plants. However, issues that may arise as production grows include:

- Uncertainty about the location of and demand from terminal markets which consolidate, transload, and distribute ethanol for blending. Change in State policies towards ethanol may decrease this uncertainty.

- Shifts in transportation demand for corn, ethanol, DDGS, and WDGs among rail, truck, and barge, in the context of overall traffic and future ethanol production locations.

- Concern about the adequacy of transportation infrastructure to efficiently ship ethanol and co-products.

- Increased transportation demand for agricultural inputs, mainly additional fertilizer for increased corn acreage.

\footnotetext{
${ }^{6}$ U. S. Department of Transportation, Federal Highway Administration, Office of Freight Management and Operations, Freight Analysis Framework, 2006.

${ }^{7}$ Federal Highway Administration; "The U.S. Truck Driver Shortage: Analysis and Forecasts." Global Insight, May 2005.
} 
- Expected long-term growth in overall freight volumes-U.S. Department of Transportation projects total inter-city freight by all modes to grow dramatically from 19.3 billion tons in 2002 to 37.2 billion tons in $2035 .^{8}$

\section{Ethanol Production Scenarios and Transportation}

The increased use of corn for ethanol has raised corn prices, and has resulted in increased corn production in the United States and changes in grain transportation as corn use shifts from exports and feed use to ethanol production. In August, USDA forecast corn production for the 2007/08 marketing year to reach about 13.05 billion bushels, up 2.5 billion bushels ( 24 percent) from last year. Increased grain production typically causes transportation demand to increase. Rapid ethanol production expansion, however, may affect where corn is transported and by which transportation mode. For example:

- Much of the increase in the corn crop will be trucked to ethanol facilities. Trucks currently dominate the local transportation of corn to ethanol plants. Should this trend continue, it may lead to a shift in modal share of grain transportation. However, as corn production is expected to continue to increase, demand for grain transportation for all modes may rise proportionately.

- In August, USDA projected 2007/08 corn exports at 2.15 billion bushels (up 50 million bushels from last year). Projected corn exports, however, decline in 2008/09 and 2009/10 before increasing in subsequent years, which leads to variability in overall rail and barge transportation demand, assuming the historical 5-year average modal share stays the same (Appendix I, Table 4 footnotes) ${ }^{9}$.

- Price competition in different locations (corn basis) may shift transportation patterns more frequently than in the past because corn used for fuel has created an additional demand for corn and corn origination patterns may change as ethanol production increases. However, if corn supplies are abundant, there may be less price competition and thus fewer shifts in transportation patterns.

Transportation shifts are expected to continue over the next several years, until commodity markets adjust to sustained ethanol production. Since most of the export grain is shipped by rail and barge, a reduction in grain exports may reduce grain movements by these modes.

Transportation requirements could increase as ethanol production reaches 15 billion gallons by 2016; demand for rail and barge services then may recede as export demand decreases under the 20 billion gallon scenario (figures 4-6 and Appendix I, Tables 1-3). In the near-term, however, sharp increases in ethanol and DDGS movements are expected to offset any decreases in rail and barge grain transportation due to decreased exports and domestic use. Trucking demand continues to grow for all three scenarios, increasing most dramatically as ethanol production grows from the baseline to the 15-billion gallon target.

\footnotetext{
${ }^{8}$ U.S. DOT - Freight Analysis Framework, 2002 and 2006.

${ }^{9}$ Changes in market conditions and transportation costs may change modal shares for grains, ethanol, and coproducts.
} 

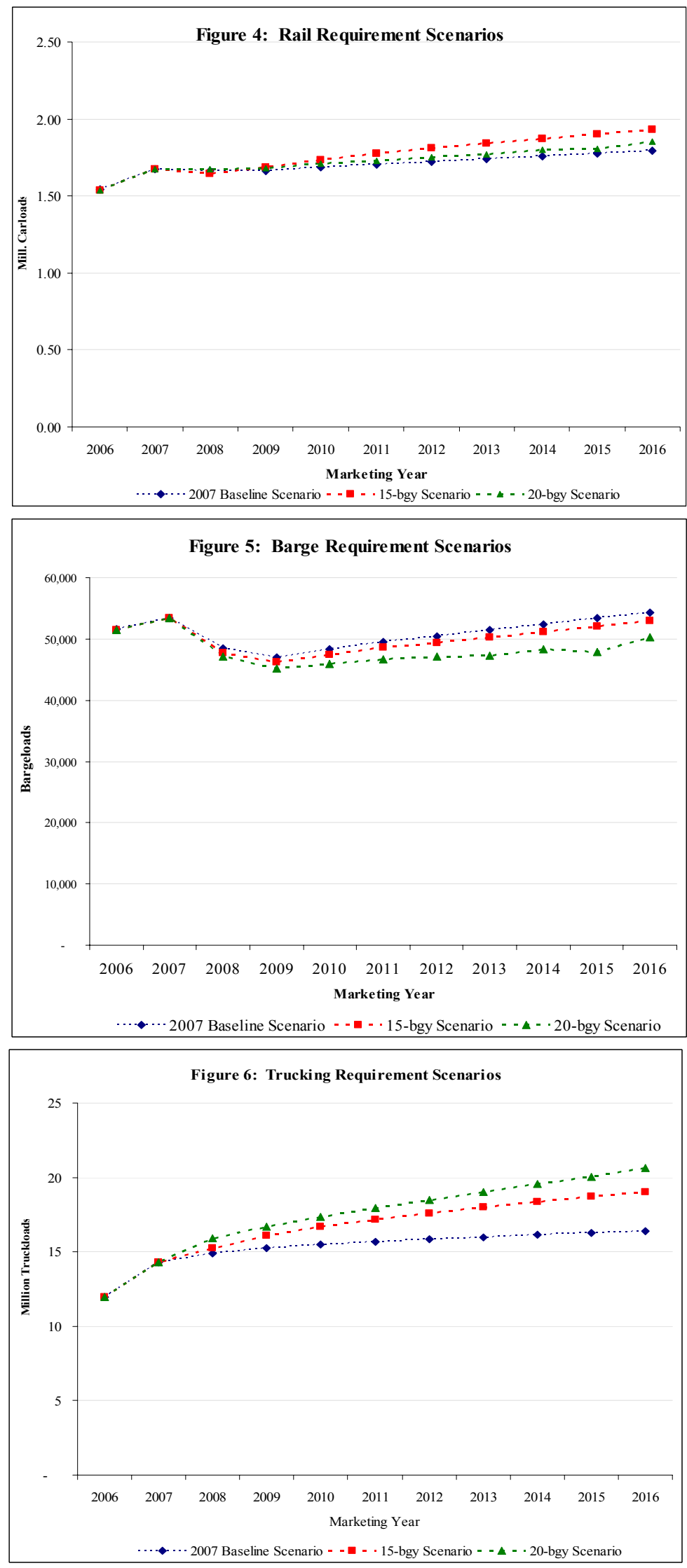
Increased ethanol production could lead major corn-producing states to become corndeficit states, resulting in the need to source corn from other states and increasing transportation distances for sourced feedstock. Corn prices are expected to vary by location to ration the demand between domestic feedlots, ethanol plants, and exports. For example, as demand for corn at ethanol plants increases, corn prices may strengthen near the ethanol-producing areas relative to corn prices in export locations. This impact is demonstrated by the corn basis, which is the difference between the local cash

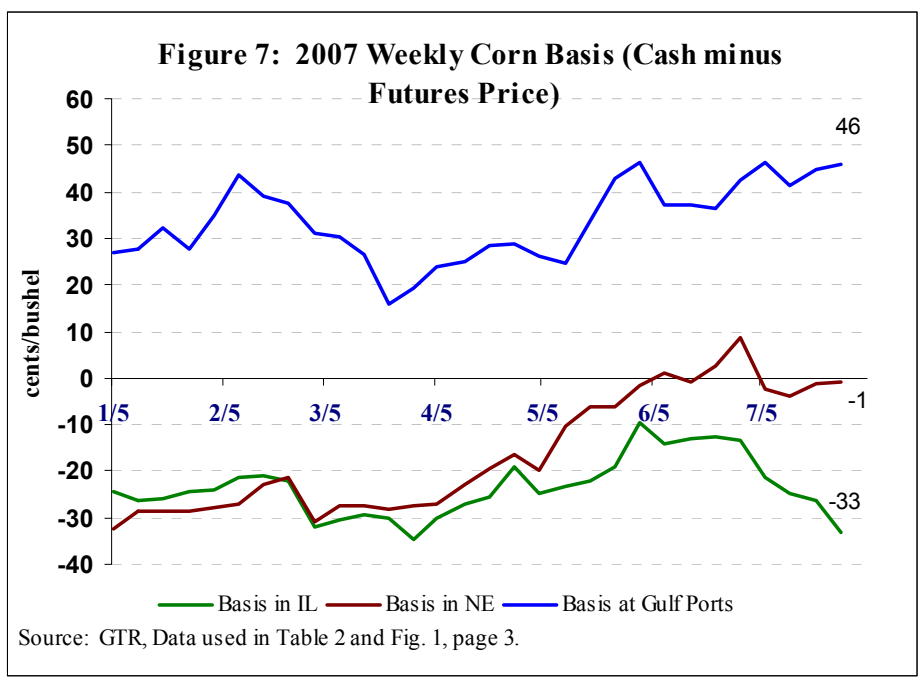
prices and the nearby Chicago Board of Trade futures contract. Transportation demand may be higher in the areas with stronger prices (stronger basis). Increases in transportation costs, however, may also weaken (decrease) the interior basis, which would cause farm prices to fall in those locations.

The domestic corn basis during the first half of 2007 has been strengthening relative to exports until recently (Figure 7). Corn futures prices have been decreasing from the high of over $\$ 4.00$ in the spring to $\$ 3.20$ by the end of July. However, the corn basis in Nebraska and at the Gulf ports have been strong, indicating relatively stronger demand in those locations for ethanol and export use.

\section{$\underline{\text { Rail }}$}

Railroads shipped about 60 percent of ethanol produced in the United States in 2005, or 82,483 carloads (Figure 8) and have kept up with the annual ethanol production growth of 26 percent in 2006. According to preliminary Freight Commodity Statistics, the Class I railroads' origination of all alcohols ${ }^{10}$ grew by 28 percent.

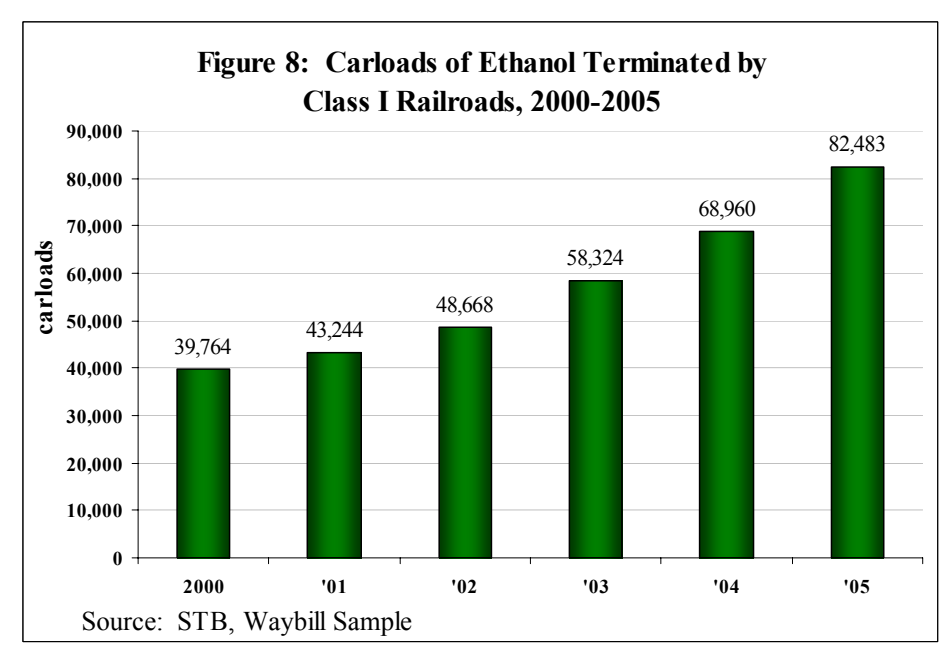

\footnotetext{
${ }^{10}$ Preliminary data does not include ethanol-specific statistics, but nearly all growth in alcohol movements during 2006 is expected to be from increased ethanol movement. Freight Commodity Statistics, compiled by Escalation Consultants, Inc.
} 
The expected growth in rail movements of ethanol may pose some hurdles for shippers. Ethanol volumes moved by rail could jump from the projected 190,816 carloads in 2007 to over 408,000 in 2016 (table 4). Class I railroads, however, assert that the additional volume due to ethanol is well below the 20.8 million carloads of cargo freight they originated in 2006 .

The variability and uncertainty of rail grain transportation demand is a function of grain export projections. For example, in the 20-bgy scenario, projected grain exports decline and rail grain transportation demand would decrease. However, that decrease is more than offset by the increased demand for ethanol and DDGS rail transportation. The consequences of the increased ethanol and DDGS transportation under the 20-bgy scenario occurring during a relatively short period could include a strain on rail transportation and logistics infrastructure. Thus, the interdependence of corn used for fuel vs. corn used for feed (domestic and exports) may translate into uncertainty for rail transportation.

\begin{tabular}{|c|c|c|c|c|c|c|c|}
\hline & 2006 & 2007 & 2008 & 2009 & 2010 & 2016 & $\begin{array}{r}10-y r \\
\text { Change }\end{array}$ \\
\hline \multicolumn{8}{|l|}{ Ethanol } \\
\hline Baseline & 119,347 & 190,816 & 208,163 & 219,592 & 225,306 & 245,306 & 125,959 \\
\hline 15-bgy & 119,347 & 190,816 & 227,755 & 245,551 & 257,633 & 306,122 & 186,776 \\
\hline 20-bgy & 119,347 & 190,816 & 248,163 & 276,163 & 298,449 & 408,163 & 288,816 \\
\hline \multicolumn{8}{|l|}{ All Grain } \\
\hline Baseline & $1,395,263$ & $1,441,309$ & $1,406,463$ & $1,395,589$ & $1,412,880$ & $1,493,286$ & 98,023 \\
\hline 15-bgy & $1,393,606$ & $1,441,309$ & $1,369,997$ & $1,390,367$ & $1,423,634$ & $1,560,152$ & 166,546 \\
\hline 20-bgy & $1,393,606$ & $1,441,309$ & $1,371,766$ & $1,343,115$ & $1,344,955$ & $1,357,424$ & $-36,182$ \\
\hline \multicolumn{8}{|l|}{ DDGS } \\
\hline Baseline & 26,338 & 41,650 & 45,325 & 47,775 & 49,000 & 53,288 & 26,950 \\
\hline 15-bgy & 26,338 & 41,650 & 49,533 & 53,403 & 56,030 & 66,576 & 40,239 \\
\hline 20-bgy & 26,338 & 41,650 & 53,971 & 60,061 & 64,907 & 88,768 & 62,431 \\
\hline
\end{tabular}

\section{Unit Train Economics}

It is more efficient and cost effective for railroads to move unit trains. The primary reasons include a higher asset utilization rate and lower inventory carrying costs. The industry "rule of thumb" is that the ethanol railcar utilization rate for a unit train is 30 turns per year, compared to 12 turns per year for a single-car shipment. Inventory carrying costs (travel, dwell, and unloading times) for a single-car shipment of ethanol could be as much as four-times that of a unit train. Unit train movements would increase the average number of loadings per year for each ethanol tank car, which could help alleviate potential tank car shortages. 
Rail tariff rates for unit trains are typically lower than those for single-car and smaller shipments. For example, BNSF's tariff rate is discounted $\$ 900$ for a gathered unit train of ethanol vs. a single car shipment of ethanol from Southwest Iowa to the Los Angeles Basin, California (Table 5).

Table 5: Sample BNSF Tariff Rates, effective October, 2007 (excludes fuel surcharges)

\begin{tabular}{|c|c|c|c|c|c|}
\hline \multirow[b]{2}{*}{ Sample Route } & \multirow[b]{2}{*}{ Unit Train } & \multirow[b]{2}{*}{ Gathered } & \multirow[b]{2}{*}{ Single Car } & \multicolumn{2}{|c|}{ Discount } \\
\hline & & & & $\begin{array}{l}\text { Unit vs. } \\
\text { Gathered }\end{array}$ & $\begin{array}{l}\text { Gathered } \\
\text { vs. Single }\end{array}$ \\
\hline \multirow{4}{*}{$\begin{array}{l}\text { From SW IA to IL } \\
\text { From SW IA to CA, LA Basin }\end{array}$} & \multicolumn{5}{|c|}{$\$ /$ car } \\
\hline & $\$ 2,100$ & $\$ 2,500$ & $\$ 2,900$ & $-\$ 400$ & $-\$ 400$ \\
\hline & $\$ 3,900$ & $\$ 4,400$ & $\$ 5,300$ & $-\$ 500$ & $-\$ 900$ \\
\hline & \multicolumn{5}{|c|}{ \$/gal } \\
\hline From SW IA to IL & $\$ 0.07$ & $\$ 0.09$ & $\$ 0.10$ & $-\$ 0.014$ & $-\$ 0.01$ \\
\hline From SW IA to CA, LA Basin & $\$ 0.13$ & $\$ 0.15$ & $\$ 0.18$ & $-\$ 0.017$ & $-\$ 0.03$ \\
\hline \multicolumn{6}{|c|}{ UNIT TRAIN: a 95-car ethanol train originating at 1 plant } \\
\hline \multicolumn{6}{|c|}{ GATHERED TRAIN: originating at 2 or 3 plants } \\
\hline
\end{tabular}

http://www.bnsf.com/markets/agricultural/ag_news/year2007/pricing07/p08-23-07a.html

Construction of unit train infrastructure at destination terminals - mostly owned by blenders, refiners, and third-party providers - may become a key to the efficiency of rail ethanol transportation. Factors that may be contributing to a slower rate of the infrastructure development include its capital-intensive nature as well as the sometimes-lengthy permitting process. Locations that are either capable of accepting unit trains of ethanol or currently expanding that capacity include:

- Watson, Carson and Stockton, CA

- Providence, RI

- Ft. Worth and Arlington, TX

- Sewaren and Linden, NJ

- Albany, NY

- Baltimore, MD

Future demand locations could include population centers in the Southeast, the Gulf Coast and Delta Region, and the Pacific Northwest. New terminal facilities that consolidate smaller ethanol shipments from different plants into unit trains are under construction in Manly, IA, and Sauget (near St. Louis), MO.

Similar economics are developing in the DDGS rail shipments. Unit trains of DDGS are currently discounted on BNSF by approximately $\$ 7.50$ per ton relative to single car movements. ${ }^{11}$ Additional DDGS storage at origin and unit train unloading infrastructure at destination would encourage further unit train utilization of DDGS.

\footnotetext{
${ }^{11}$ http://www.bnsf.com/markets/agricultural/ag_news/year2007/pricing07/p06-14-07a.html
} 


\section{INFRASTRUCTURE ISSUES}

\section{Supply Chain Issues}

Several supply chain issues could inhibit growth in the ethanol industry. The efficiency of the ethanol transportation system may begin to depend on the ability of the blending market to accommodate additional quantities of ethanol.

The supply and demand of ethanol may become temporarily out of balance because blenders require time and financial incentives to add blending capacity. These extra financial incentives, including cheaper ethanol, could be in addition to the current blender tax credit of $\$ 0.51$ per gallon, which is in place through 2010. Blenders are watching Federal and State legislative processes carefully to assess the legislative risk to their capital investments.

Grain markets may also be affected by ethanol supply chain issues. There is concern that grain storage shortages may occur as ethanol production capacity and corn crops continue to expand.

\section{Rail Capacity}

Rail capacity typically depends on several factors, including locomotive power and railcar availability and utilization, which are affected by train speeds, dwell time, loading and unloading times, and track capacity. In addition to an efficient logistics infrastructure, an adequate supply of railcars and other transportation equipment for ethanol and DDGS are needed to sustain growth in the ethanol industry.

\section{Ethanol Rail Tank Cars}

Ethanol is shipped in standard rail tank cars (approved for flammable liquids)—DOT 111A or AAR T108 rail cars (Appendix II). As of January $1,2007,41,000$ rail tank cars capable of shipping ethanol were in use. Orders for new cars increased substantially in 2006 with a surge in ethanol plant construction and are expected to almost double this fleet in the next $2-2 \frac{1}{2}$ years. Rail tank cars are nearly all privately owned, either by leasing

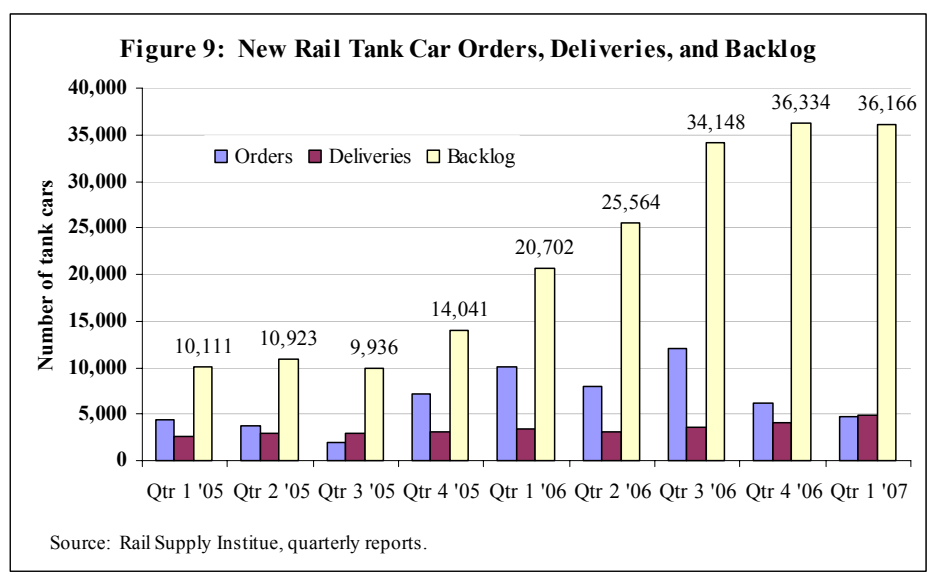
companies or shippers. Orders for new rail tank cars, 75 percent of which are estimated to be for ethanol use, started to increase in the $4^{\text {th }}$ quarter 2005 and continued to increase through the $3^{\text {rd }}$ quarter 2006 (Figure 9). Rail tank car manufacturers increased production lines, but the backlog grew from about 10,000 railcars in the $3^{\text {rd }}$ quarter 2005 to a peak of 36,334 railcars in the $4^{\text {th }}$ quarter 2006. By the end of $1^{\text {st }}$ quarter 2007, the manufacturing backlog had decreased to 36,166 railcars. 


\section{Grain Rail Cars}

Increased rail service demand is expected to affect railcar fleet composition and availability for moving corn, ethanol, and DDGS. ${ }^{12}$ Most grain is shipped in designated covered hopper railcars C113, C114, C213, or C313, which can also be used for other dry bulk commodities (Appendix II). Total covered hopper railcar fleet as of January 1, 2007, was 268,000 railcars-almost 2 percent higher than on January 1,2005. However, the grain rail car fleet share is estimated to be approximately $160,800-60$ percent of the total covered hopper fleet.

\section{Distillers Dried Grains with Solubles (DDGS) Transportation Issues}

Ethanol plants that use corn as feedstock produce a co-product called distillers grains (DDGSdried distillers grains with solubles, WDG-wet distillers grains, and MDG-modified distillers grains $)^{13}$. For every 56-pound bushel of corn, 17.5 pounds of DDGS and 2.76 gallons of ethanol are produced, on average. Dairy cattle operations and cattle feedlots are the primary domestic users of distilled grains as a protein supplement for the ruminant animals. Research is ongoing for increasing the DDGS use by poultry and hog operations, which currently is limited due to nutritional challenges DDGS present to non-ruminant animals.

Production of DDGS is expected to grow proportionately with ethanol production increases. Currently, about 10 percent of DDGS are exported-1.25 million metric tons (mt) in 2006. According to the USDA's Foreign Agricultural Service (FAS), the United States exported approximately 900,000 metric tons of DDGS during the first 6 months of 2007-60 percent higher than the same period last year. The trend of increased DDGS exports is expected to continue. Increased use of barges to ship DDGS to export locations is likely.

The original co-product of distilled grains from ethanol production is wet distillers grains (WDG). Shipping the WDG's saves energy, but the product is perishable and needs to be trucked to a nearby feeding operation within a couple of days. Drying the product adds cost for the ethanol producer, but provides a more stable product for transport and storage. Railroads and barges ship DDGS long distances and trucks are used for shorter distances.

Demand for shipping DDGS to domestic and export markets has been increasing, thus expanding demand for super jumbo covered hoppers - railcars that are greater than 5,500 cubic feet $\left(\mathrm{ft}^{3}\right)$ and have wide gates for easier flowability. During storage and transport, DDGS tends to cake and bridge between particles. Thus, flowability has become one of the major issues that needs to be addressed for effective sales, marketing, distribution, and utilization of distillers grains. Because these co-products do not always flow easily from railcars, workers sometimes hammer the car sides and hopper bottoms in order to induce flow. This can lead to severe damage to the rail cars themselves and can also pose worker safety issues.

\footnotetext{
${ }^{12}$ Railcar fleet statistics are from Association of American Railroads, telephone conversation with Craig Rockey on July 3, 2007.

${ }^{13}$ http://www.usda.gov/oce/reports/energy/USDA_2002_ETHANOL.pdf
} 
According to the Rail Supply Institute, from first quarter 2005 through first quarter 2007, new deliveries of super jumbo railcars have totaled 11,307 , with most of the growth occurring in 2006. DDGS are estimated to use about 70 percent of this fleet (Figure 10). DDGS railcars are nearly all privately owned.

Flowability issues associated with shipping DDGS,

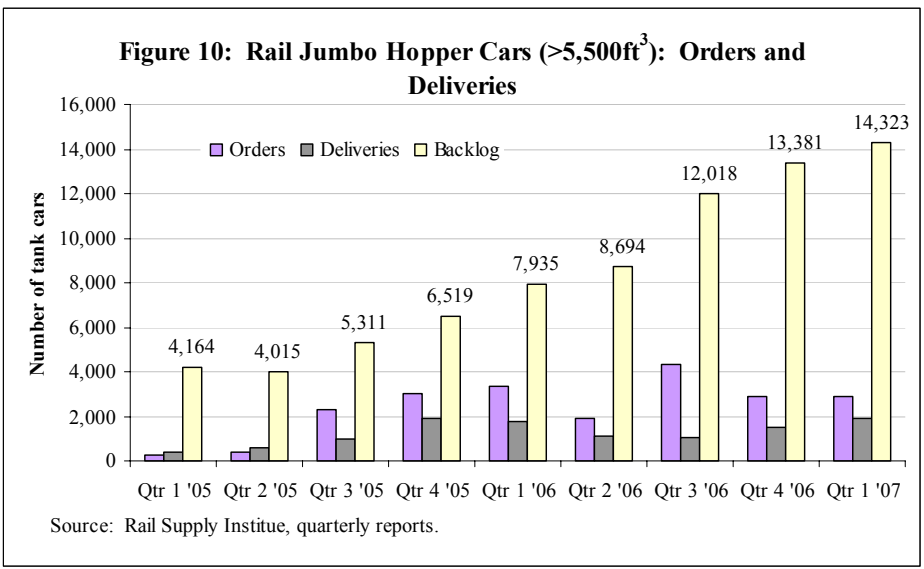
based on the feed industry experience of using regular grain covered hoppers, have created expectations of a shorter lifespan for railcars used to ship DDGS. DDGS are also shipped in containers for export. The same flowability issues have started to affect availability of containers. DDGS transportation may be affected if feedlot operations move closer to the ethanol producing areas - more distillers' grains would be sold wet, requiring less rail and more truck transportation to feedlots and decreasing availability of DDGS for export.

\section{Truck Service}

Corn for ethanol is most frequently delivered to plants by trucks, typically from corn farms within a 50-mile radius. The truckload requirements just for corn to ethanol-if trucks are assumed to carry 98 percent of the corn delivered to ethanol plants - are expected to increase from 2.3 million in 2006 to 4.7 million truckload equivalents by 2016 . The demand for corn trucking increases substantially - to 5.9 and 7.8 million truckloads under scenarios 1 and 2, respectively (table 6).

\begin{tabular}{|c|c|c|c|c|c|c|c|}
\hline & 2006 & 2007 & 2008 & 2009 & 2010 & 2016 & $\begin{array}{r}10-\mathrm{yr} \\
\text { Change }\end{array}$ \\
\hline \multicolumn{8}{|c|}{ Domestic and Export Corn } \\
\hline Baseline & 5.29 & 5.30 & 5.33 & 5.30 & 5.33 & 5.55 & 0.3 \\
\hline 15-bgy & 5.29 & 5.30 & 5.08 & 5.32 & 5.49 & 6.20 & 0.9 \\
\hline 20-bgy & 5.29 & 5.30 & 5.09 & 4.95 & 4.87 & 4.61 & -0.7 \\
\hline \multicolumn{8}{|c|}{ Corn for Fuel Use } \\
\hline Baseline & 2.32 & 3.66 & 3.98 & 4.20 & 4.31 & 4.68 & 2.4 \\
\hline 15-bgy & 2.32 & 3.66 & 4.35 & 4.69 & 4.93 & 5.85 & 3.5 \\
\hline 20-bgy & 2.32 & 3.66 & 4.74 & 5.28 & 5.71 & 7.80 & 5.5 \\
\hline
\end{tabular}

Standard gasoline tanker trucks (DOT MC306 Bulk Fuel Haulers) are used to ship ethanol from ethanol plants to the blending terminals. These trucks move an estimated 30 percent of ethanol. The current fleet size of the independently operated tank trucks is approximately 10,000. Many petroleum companies own their tanker truck fleet and are not included in the total. 
Constraints to truck service include the availability of truck drivers (especially with HAZMAT certification), equipment shortages, and the differences in ethanol routes from the well-established and predictable petroleum routes - in part due to the rapid growth of new ethanol plant construction. In addition, overall truck freight is forecast to almost double from 2002 to 2020 , while driver shortages are projected to reach 219,000 by 2015 . In 2004, there were 1.3 million long-haul heavy-duty truck drivers.

\section{Tank Barge Service}

Barges move an estimated 10 percent of ethanol. The main terminals served by barge include Chicago, IL, New Orleans, LA, Houston, TX, and Albany, NY. Ethanol is typically shipped in $10,000-15,000$ barrel $^{14}$ tank barges. The number of ethanol plants located near a river facility, however, is relatively small. As the industry grows, the share moved by barge may increase. According to Informa Economics, 2,808 tank barges were in operation in 2006, up from 2,782 in 2005, and 2,777 in 2004. Construction of a 16.6-million-gallon ethanol terminal on the Mississippi River at Sauget, IL, is expected to be completed by June 2008. The Army Corps of Engineers has approved construction of a 5th ethanol storage tank at this location to hold an additional 480,000 gallons by the third quarter of 2008. The terminal will be capable of loading 1.26-million-gallon tank barges as well as 95-car unit trains and trucks.

\section{Potential Pipeline Developments}

Pipelines are considered to be the safest and most cost-efficient mode of transportation. The ethanol industry, however, is fairly dispersed and significant infrastructure investments would still be necessary to consolidate sufficient quantities that could then be moved through pipelines.

No ethanol is currently shipped by pipeline due to its corrosive nature and ability to attract water. The pipeline industry, however, led by the Association of Oil Pipe Lines (AOPL) and American Petroleum Institute (API), is moving forward with an accelerated research program to address integrity issues related to shipping ethanol/gasoline blends. The project, managed by the Pipeline Research Council International (PRCI), will focus on an accelerated research effort due to be concluded in 6-12 months. It plans to identify those blends that:

- Can be moved in existing pipelines with little to no modification to the system.

- Can be moved with appreciable modifications.

- Cannot be moved in existing systems but could be moved in specially designed new transmission or short-haul distribution systems.

If and when pipelines are able to ship ethanol blends, it could alleviate potential strain on the rail system. Federal Energy Regulatory Commission and Pipeline Hazardous Materials Safety Administration (PHMSA) regulate the pipeline industry. PHMSA is currently accepting comments on the adequacy of existing regulatory definitions and standards regarding bio-fuels and pipeline safety. Comments are also welcomed on short- and long-term opportunities and challenges associated with transporting biofuels. (http://dms.dot.gov)

${ }^{14} 1$ barrel $=42$ gallons. 


\section{Government Biofuel Activities}

The Federal government support for a biofuel economy continues to be strong as defined by the national energy policy goals. Transportation issues associated with higher ethanol production targets and biomass feedstock will have to be evaluated as the new technology and other biofuels become a market reality. USDA and DOE co-chair the legislatively-mandated federal Biomass Research and Development (R\&D) Board aimed at coordinating the Executive Branch activities to promote the use of biofuels.

The 2002 Farm Bill for the first time included Energy in its title. The 2007 Farm Bill, working its way through Congress, includes several provisions aimed at increasing biofuel production, especially cellulosic-based fuels, and the bioenergy sector in general.

State government energy policies vary greatly and are likely to change as the national energy policy goals are translated into regional policy goals. The current (August 2007) status of State ethanol incentives is as follows. ${ }^{15}$

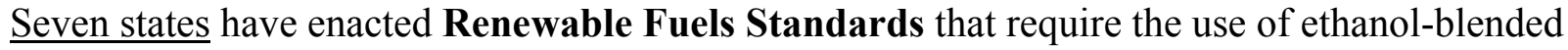
fuel: Hawaii, Iowa, Louisiana, Minnesota, Missouri, Montana, and Washington. In addition, California legislature is expected to enact the higher ethanol blending rule in the fall of 2007.

Fourteen states have retailer incentives for ethanol blends and E-85: Alaska, Connecticut, Hawaii, Idaho, Illinois, Indiana, Iowa, Kansas, Maine, Missouri, Minnesota, North Dakota, Oklahoma, and South Dakota.

Twenty-two states have some type of incentive for ethanol producers: Hawaii, Illinois, Indiana, Kansas, Maine, Maryland, Minnesota, Mississippi, Missouri, Montana, Nebraska, New York, North Dakota, Oklahoma, Oregon, Pennsylvania, South Carolina, South Dakota, Tennessee, Texas, Virginia, and Wyoming.

\footnotetext{
${ }^{15}$ Sources: American Coalition for Ethanol, and the Renewable Fuels Association http://www.ethanol.org/index.php?id=79\&parentid=26) and http://www.ethanolrfa.org/policy/actions/state/
} 


\section{APPENDIX I - Scenario Tables}

Table 1: Baseline Scenario for Transportation Requirements Based on Agricultural Projections to 2016 and World Agricultural Supply and Demand Estimates, August 10, 2007*.

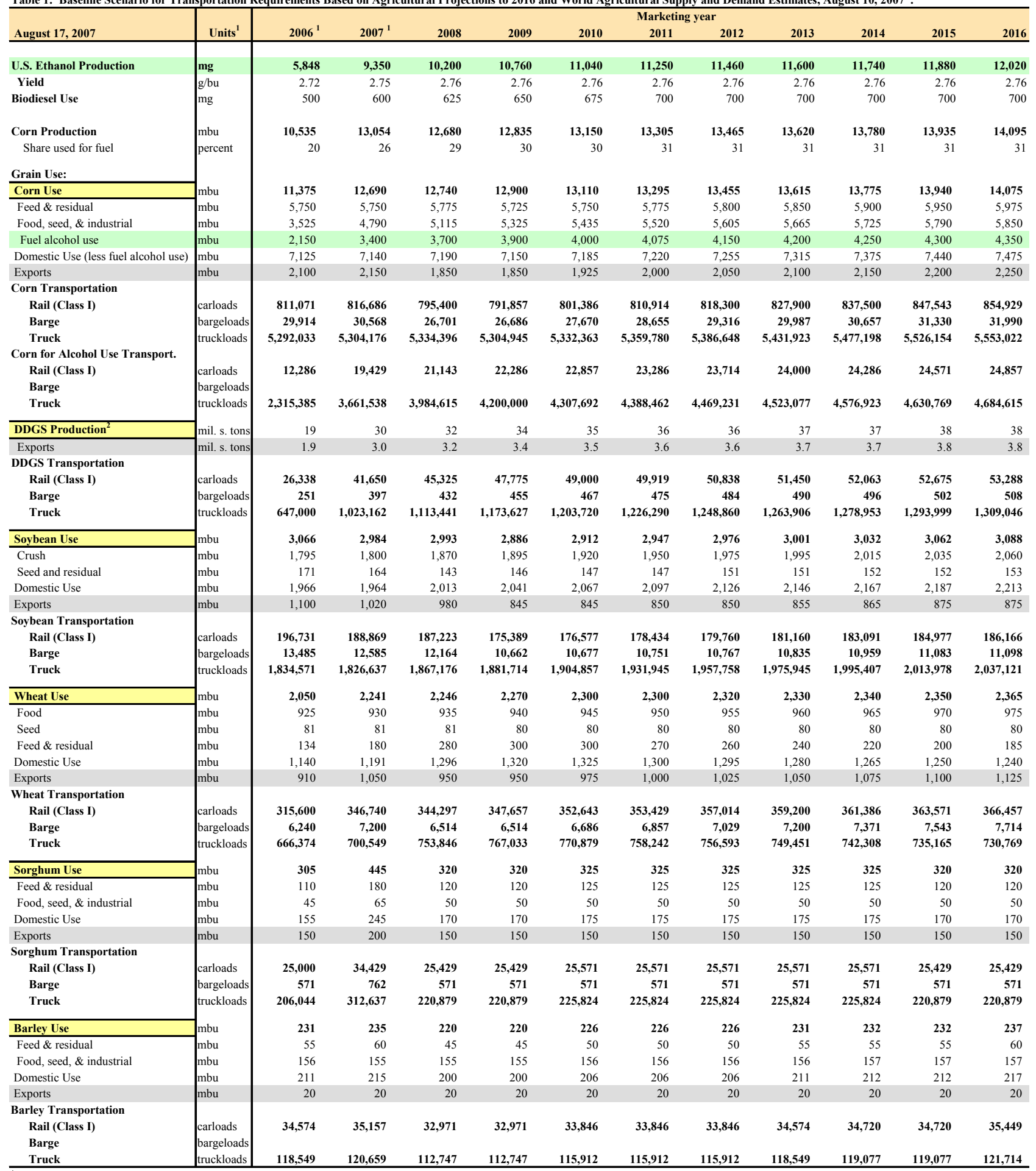

"See Transportation Assumptions in the Summary of Transportation Requirements Table 4, Appendix I; USDA Long-term Projections Report, OCE-2007-1, February 2007.

Units: $\mathrm{mg}=$ million gallons; $\mathrm{mbu}=$ million bushels; $\mathrm{mil} . \mathrm{s}$. tons $=$ million short tons.

${ }^{1}$ USDA, World Agricultural Supply and Demand Estimates (WASDE), August 10, 2007.

${ }^{2} \mathrm{DDGS}$ yield $=17.5 \mathrm{lbs} / \mathrm{bushel}$ of corn used in ethanol production. 
Table 2: Transportation Requirements Based on a 15-bgy Scenario* and August 12, 2007 WASDE for 2006 and 2007.

\begin{tabular}{|c|c|c|c|c|c|c|c|c|c|c|c|c|}
\hline \multirow[b]{2}{*}{ August 17, 2007} & \multirow[b]{2}{*}{ Units $^{1}$} & \multirow[b]{2}{*}{$2006^{1}$} & \multirow[b]{2}{*}{$2007^{1}$} & \multirow[b]{2}{*}{2008} & \multirow[b]{2}{*}{2009} & \multicolumn{3}{|c|}{ Marketing year } & \multirow[b]{2}{*}{2013} & \multirow[b]{2}{*}{2014} & \multirow[b]{2}{*}{2015} & \\
\hline & & & & & & 2010 & 2011 & 2012 & & & & 2016 \\
\hline U.S. Ethanol Production & mg & 5,848 & 9,350 & 11,160 & 12,032 & 12,624 & 13,125 & 13,584 & 13,980 & 14,348 & 14,688 & 15,000 \\
\hline Yield & $\mathrm{g} / \mathrm{bu}$ & 2.72 & 2.75 & 2.76 & 2.76 & 2.76 & 2.76 & 2.76 & 2.76 & 2.76 & 2.76 & 2.76 \\
\hline Biodiesel Use & $\mathrm{mg}$ & 500 & 600 & 700 & 755 & 805 & 850 & 880 & 910 & 940 & 970 & 1,000 \\
\hline Corn Production & mbu & 10,535 & 13,054 & 12,781 & 12,945 & 13,325 & 13,497 & 13,715 & 13,878 & 14,091 & 14,249 & 14,45 \\
\hline Share used for fuel & percent & 20 & 26 & 32 & 34 & 34 & 35 & 36 & 36 & 37 & 37 & 38 \\
\hline Grain Use: & & & & & & & & & & & & \\
\hline Corn Use & $\mathrm{mbu}$ & 11,375 & 12,690 & 12,686 & 13,305 & 13,811 & 14,245 & 14,635 & 14,971 & 15,299 & 15,609 & 15,901 \\
\hline Feed \& residual & $\mathrm{mbu}$ & 5,750 & 5,750 & 5,434 & 5,754 & 5,975 & 6,163 & 6,337 & 6,487 & 6,629 & 6,764 & 6,886 \\
\hline Food, seed, \& industrial & mbu & 3,525 & 4,790 & 5,454 & 5,775 & 5,995 & 6,183 & 6,357 & 6,508 & 6,649 & 6,785 & 6,907 \\
\hline Fuel alcohol use & mbu & 2,150 & 3,400 & 4,043 & 4,359 & 4,574 & 4,755 & 4,922 & 5,065 & 5,199 & 5,322 & 5,435 \\
\hline Domestic Use (less fuel alcohol use) & mbu & 7,125 & 7,140 & 6,845 & 7,170 & 7,397 & 7,591 & 7,772 & 7,930 & 8,079 & 8,228 & 8,358 \\
\hline Exports & mbu & 2,100 & 2,150 & 1,797 & 1,776 & 1,840 & 1,898 & 1,941 & 1,976 & 2,021 & 2,060 & 2,108 \\
\hline Corn Transportation & & & & & & & & & & & & \\
\hline Rail (Class I) & carloads & 811,071 & 816,686 & 760,356 & 787,278 & 812,884 & 835,045 & 854,742 & 871,718 & $\mathbf{8 8 8 , 7 9 5}$ & 905,286 & 920,956 \\
\hline Barge & bargeloads & 29,914 & 30,568 & 25,888 & 25,738 & 26,655 & 27,476 & 28,100 & 28,613 & 29,252 & 29,811 & 30,489 \\
\hline Truck & truckloads & $5,292,033$ & $5,304,176$ & $5,079,445$ & $5,317,800$ & $5,486,406$ & $5,630,781$ & $5,764,938$ & $5,881,897$ & $5,992,790$ & $6,103,106$ & $6,199,884$ \\
\hline Corn for Alcohol Use Transport. & & & & & & & & & & & & \\
\hline Rail (Class I) & carloads & 12,286 & 19,429 & 23,106 & 24,911 & 26,137 & 27,174 & 28,124 & 28,944 & 29,706 & 30,410 & 31,056 \\
\hline Barge & bargeloads & & & & & & & & & & & \\
\hline Truck & truckloads & $2,315,385$ & $3,661,538$ & $4,354,515$ & $4,694,760$ & $4,925,753$ & $5,121,237$ & $5,300,334$ & $5,454,849$ & $5,598,439$ & $5,731,104$ & $5,852,843$ \\
\hline DDGS Production $^{2}$ & mil. s. tons & 19 & 30 & 35 & 38 & 40 & 42 & 43 & 44 & 45 & 47 & 48 \\
\hline Exports & mil. s. tons & 1.9 & 3.0 & 3.5 & 3.8 & 4.0 & 4.2 & 4.3 & 4.4 & 4.5 & 4.7 & 4.8 \\
\hline DDGS Transportation & & & & & & & & & & & & \\
\hline Rail (Class I) & carloads & 26,338 & 41,650 & 49,533 & 53,403 & 56,030 & 58,254 & 60,291 & 62,049 & 63,682 & 65,191 & 66,576 \\
\hline Barge & bargeloads & 251 & 397 & 472 & 509 & 534 & 555 & 574 & 591 & 606 & 621 & 634 \\
\hline Truck & truckloads & 647,000 & $1,023,162$ & $1,216,804$ & $1,311,880$ & $1,376,428$ & $1, \mathbf{4 3 1}, \mathbf{0 5 3}$ & $1,481,099$ & $1,524,276$ & $1,564,400$ & $1,601,471$ & $1,635,489$ \\
\hline Soybean Use & $\mathrm{mbu}$ & 3,041 & 2,984 & 2,985 & 2,881 & 2,899 & 2,935 & 2,957 & 2,985 & 3,011 & 3,045 & 3,066 \\
\hline Crush & mbu & 1,780 & 1,800 & 1,876 & 1,906 & 1,929 & 1,960 & 1,984 & 2,008 & 2,029 & 2,054 & 2,080 \\
\hline Seed and residual & mbu & 171 & 164 & 143 & 145 & 146 & 146 & 150 & 150 & 151 & 151 & 152 \\
\hline Domestic Use & mbu & 1,951 & 1,964 & 2,019 & 2,051 & 2,075 & 2,106 & 2,134 & 2,158 & 2,180 & 2,205 & 2,232 \\
\hline Exports & mbu & 1,090 & 1,020 & 966 & 830 & 824 & 829 & 822 & 827 & 831 & 841 & 835 \\
\hline Soybean Transportation & & & & & & & & & & & & \\
\hline Rail (Class I) & carloads & 195,074 & 188,869 & 186,105 & 174,425 & 174,901 & 176,790 & 177,455 & 178,989 & 180,338 & 182,444 & 183,100 \\
\hline Barge & bargeloads & 13,364 & 12,585 & 12,006 & 10,503 & 10,444 & 10,518 & 10,461 & 10,526 & 10,580 & 10,707 & 10,654 \\
\hline Truck & truckloads & $1,820,451$ & $1,826,637$ & $1,871,377$ & $1,889,641$ & $1,910,731$ & $1,938,352$ & $1,963,146$ & $1,984,734$ & $2,004,291$ & $2,026,992$ & $2,050,784$ \\
\hline Wheat Use & $\mathrm{mbu}$ & 2,050 & 2,241 & 2,245 & 2,267 & 2,295 & 2,295 & 2,314 & 2,323 & 2,332 & 2,342 & 2,355 \\
\hline Food & $\mathrm{mbu}$ & 925 & 930 & 935 & 940 & 945 & 950 & 955 & 960 & 965 & 970 & 975 \\
\hline Seed & mbu & 81 & 81 & 81 & 80 & 80 & 80 & 80 & 80 & 80 & 80 & 80 \\
\hline Feed \& residual & mbu & 134 & 180 & 285 & 304 & 305 & 277 & 269 & 250 & 231 & 212 & 197 \\
\hline Domestic Use & mbu & 1,140 & 1,191 & 1,301 & 1,324 & 1,331 & 1,307 & 1,304 & 1,290 & 1,277 & 1,262 & 1,252 \\
\hline Exports & mbu & 910 & 1,050 & 945 & 942 & 965 & 987 & 1,010 & 1,033 & 1,056 & 1,080 & 1,103 \\
\hline Wheat Transportation & & & & & & & & & & & & \\
\hline Rail (Class I) & carloads & 315,600 & 346,740 & 344,033 & 346,963 & 351,669 & 352,299 & 355,672 & 357,719 & 359,699 & 361,781 & 364,430 \\
\hline Barge & bargeloads & 6,240 & $\mathbf{7 , 2 0 0}$ & 6,478 & 6,462 & 6,616 & 6,771 & 6,924 & $\mathbf{7 , 0 8 4}$ & 7,239 & $\mathbf{7 , 4 0 4}$ & 7,564 \\
\hline Truck & truckloads & 666,374 & 700,549 & 756,154 & 769,093 & 773,467 & 761,690 & 760,893 & 754,269 & $\mathbf{7 4 7 , 7 9 0}$ & 740,843 & 736,609 \\
\hline Sorghum Use & & 305 & 445 & 326 & 329 & 337 & 338 & 342 & 341 & 346 & 341 & 343 \\
\hline Feed \& residual & mbu & 110 & 180 & 121 & 122 & 128 & 128 & 130 & 129 & 132 & 127 & 128 \\
\hline Food, seed, \& industrial & mbu & 45 & 65 & 50 & 50 & 50 & 50 & 50 & 50 & 50 & 50 & 50 \\
\hline Domestic Use & mbu & 155 & 245 & 171 & 172 & 178 & 178 & 180 & 179 & 182 & 177 & 178 \\
\hline Exports & mbu & 150 & 200 & 155 & 157 & 159 & 160 & 161 & 162 & 163 & 164 & 165 \\
\hline Sorghum Transportation & & & & & & & & & & & & \\
\hline Rail (Class I) & carloads & 25,000 & 34,429 & 26,109 & 26,460 & 26,843 & 27,010 & 27,270 & 27,342 & 27,614 & 27,523 & 27,653 \\
\hline Barge & bargeloads & 571 & 762 & 589 & 599 & 604 & 609 & 614 & 617 & 622 & 624 & 627 \\
\hline Truck & truckloads & 206,044 & 312,637 & 223,672 & 224,943 & 232,062 & 232,196 & 235,192 & 234,459 & 237,764 & 232,402 & 234,057 \\
\hline Barley Use & & 231 & 235 & 202 & 202 & 208 & 208 & 208 & 214 & 215 & 215 & 220 \\
\hline Feed \& residual & mbu & 55 & 60 & 47 & 48 & 53 & 54 & 54 & 60 & 60 & 61 & 66 \\
\hline Food, seed, \& industrial & mbu & 156 & 155 & 134 & 134 & 135 & 134 & 134 & 134 & 135 & 134 & 134 \\
\hline Domestic Use & mbu & 211 & 215 & 182 & 182 & 188 & 188 & 188 & 194 & 195 & 195 & 200 \\
\hline Exports & mbu & 20 & 20 & 20 & 20 & 20 & 20 & 20 & 20 & 20 & 20 & 20 \\
\hline Barley Transportation & & & & & & & & & & & & \\
\hline Rail (Class I) & |carloads & 34,574 & 35,157 & 30,289 & $\mathbf{3 0 , 3 3 0}$ & 31,201 & 31,261 & 31,260 & 32,053 & 32,194 & 32,243 & 32,957 \\
\hline Barge & bargeloads & & & & & & & & & & & \\
\hline Truck & truckloads & 118,549 & 120,659 & 103,037 & 103,186 & 106,339 & 106,555 & 106,554 & 109,423 & 109,931 & 110,111 & 112,695 \\
\hline
\end{tabular}

See Transportation Assumptions in the Summary of Transportation Requirements Table 5, Appendix I; USDA Long-term Projections Report, OCE-2007-1, February 2007.

Units: $\mathrm{mg}=$ million gallons; $\mathrm{mbu}=$ million bushels; $\mathrm{mil}$. $\mathrm{s}$. tons=million short tons.

${ }^{1}$ USDA, World Agricultural Supply and Demand Estimates (WASDE), August 10, 2007.

${ }^{2}$ DDGS yield $=17.5 \mathrm{lbs} /$ bushel of corn used in ethanol production. 


\begin{tabular}{|c|c|c|c|c|c|c|c|c|c|c|c|c|}
\hline \multirow[b]{2}{*}{ August 17, 2007} & \multirow[b]{2}{*}{ Units $^{1}$} & \multirow[b]{2}{*}{$2006^{1}$} & \multirow[b]{2}{*}{$2007^{1}$} & \multirow[b]{2}{*}{2008} & \multirow[b]{2}{*}{2009} & \multicolumn{4}{|c|}{ Marketing year } & \multirow[b]{2}{*}{2014} & \multirow[b]{2}{*}{2015} & \multirow[b]{2}{*}{2016} \\
\hline & & & & & & 2010 & 2011 & 2012 & 2013 & & & \\
\hline U.S. Ethanol Production & mg & 5,848 & 9,350 & 12,160 & 13,532 & 14,624 & 15,625 & 16,584 & 17,480 & 18,348 & 19,188 & 20,000 \\
\hline Yield & $\mathrm{g} / \mathrm{bu}$ & 2.72 & 2.75 & 2.76 & 2.76 & 2.76 & 2.76 & 2.76 & 2.76 & 2.76 & 2.76 & 2.76 \\
\hline Biodiesel Use & $\mathrm{mg}$ & 500 & 600 & 700 & 755 & 805 & 850 & 880 & 910 & 940 & 970 & 1,000 \\
\hline Corn Production & $\mathrm{mbu}$ & 10,535 & 13,054 & 12,877 & 13,097 & 13,564 & 13,799 & 14,108 & 14,338 & 14,711 & 14,782 & 15,464 \\
\hline Share used for fuel & percent & 20 & 26 & 34 & 37 & 39 & 41 & 43 & 44 & 45 & 47 & 47 \\
\hline Corn Use & $\mathrm{mbu}$ & 11,375 & 12,690 & 13,012 & 13,262 & 13,593 & 13,879 & 14,158 & 14,375 & 14,731 & 14,802 & 15,406 \\
\hline Feed \& residual & $\mathrm{mbu}$ & 5,750 & 5,750 & 5,465 & 5,270 & 5,163 & 5,056 & 4,966 & 4,869 & 4,840 & 4,687 & 4,771 \\
\hline Food, seed, \& industrial & $\mathrm{mbu}$ & 3,525 & 4,790 & 5,808 & 6,305 & 6,703 & 7,068 & 7,419 & 7,745 & 8,066 & 8,374 & 8,684 \\
\hline Fuel alcohol use & $\mathrm{mbu}$ & 2,150 & 3,400 & 4,406 & 4,903 & 5,299 & 5,661 & 6,009 & 6,333 & 6,648 & 6,952 & 7,246 \\
\hline Domestic Use (less fuel alcohol use) & $\mathrm{mbu}$ & 7,125 & 7,140 & 6,867 & 6,672 & 6,567 & 6,462 & 6,376 & 6,281 & 6,258 & 6,109 & 6,209 \\
\hline Exports & mbu & 2,100 & 2,150 & 1,739 & 1,687 & 1,727 & 1,755 & 1,774 & 1,761 & 1,824 & 1,741 & 1,951 \\
\hline \multicolumn{13}{|l|}{ Corn Transportation } \\
\hline Rail (Class I) & carloads & 811,071 & 816,686 & 757,264 & 735,528 & 729,674 & 722,816 & 716,764 & 707,235 & 710,699 & 690,256 & 717,156 \\
\hline Barge & bargeloads & 29,914 & 30,568 & 25,135 & 24,394 & 24,868 & 25,197 & 25,404 & 25,200 & 26,015 & 24,874 & 27,639 \\
\hline $\begin{array}{l}\text { Rail (Class I) } \\
\text { Barge }\end{array}$ & $\begin{array}{l}\text { carloads } \\
\text { bargeloads }\end{array}$ & 12,286 & 19,429 & 25,176 & 28,017 & 30,277 & 32,350 & 34,335 & 36,190 & 37,988 & 39,727 & 41,408 \\
\hline Truck & truckloads & $2,315,385$ & $3,661,538$ & $4,744,705$ & $5,280,045$ & $5,706,132$ & $6,096,711$ & $6,470,903$ & $6,820,513$ & $7,159,197$ & $7,486,957$ & $7,803,790$ \\
\hline DDGS Production $^{2}$ & mil. s. tons & 19 & 30 & 39 & 43 & 46 & 50 & 53 & 55 & 58 & 61 & 63 \\
\hline Exports & mil. s. tons & 1.9 & 3.0 & 3.9 & 4.3 & 4.6 & 5.0 & 5.3 & 5.5 & 5.8 & 6.1 & 6.3 \\
\hline DDGS Transportation & & & & & & & & & & & & \\
\hline Rail (Class I) & carloads & 26,338 & 41,650 & 53,971 & 60,061 & 64,907 & 69,350 & 73,607 & 77,583 & 81,436 & 85,164 & 88,768 \\
\hline Barge & bargeloads & 251 & 397 & 514 & 572 & 618 & 660 & 701 & 739 & 776 & 811 & 845 \\
\hline Truck & truckloads & 647,000 & $1,023,162$ & $1,325,837$ & $1,475,429$ & $1,594,493$ & $1,703,635$ & $1,808,197$ & $1,905,890$ & $2,000,530$ & $2,092,118$ & $2,180,652$ \\
\hline Soybean Use & $\mathrm{mbu}$ & 3,041 & 2,984 & 2,969 & 2,859 & 2,864 & 2,892 & 2,900 & 2,920 & 2,923 & 2,974 & 2,920 \\
\hline Crush & $\mathrm{mbu}$ & 1,780 & 1,800 & 1,868 & 1,893 & 1,909 & 1,935 & 1,951 & 1,970 & 1,979 & 2,009 & 2,000 \\
\hline Seed and residual & $\mathrm{mbu}$ & 171 & 164 & 142 & 144 & 145 & 145 & 148 & 147 & 149 & 147 & 152 \\
\hline Domestic Use & $\mathrm{mbu}$ & 1,951 & 1,964 & 2,010 & 2,037 & 2,054 & 2,079 & 2,100 & 2,117 & 2,128 & 2,155 & 2,152 \\
\hline Exports & $\mathrm{mbu}$ & 1,090 & 1,020 & 959 & 822 & 810 & 813 & 800 & 803 & 795 & 819 & 768 \\
\hline Soybean Transportation & & & & & & & & & & & & \\
\hline Rail (Class I) & carloads & 195,074 & 188,869 & 185,064 & 172,980 & 172,563 & 173,978 & 173,745 & 174,766 & 174,483 & 178,041 & 172,984 \\
\hline Barge & bargeloads & 13,364 & 12,585 & 11,928 & 10,401 & 10,273 & 10,320 & 10,195 & 10,230 & 10,148 & 10,431 & 9,860 \\
\hline Food & mbu & 925 & 930 & 936 & 941 & 946 & 951 & 956 & 961 & 966 & 971 & 975 \\
\hline Seed & mbu & 81 & 81 & 81 & 79 & 79 & 79 & 79 & 79 & 79 & 79 & 80 \\
\hline Feed \& residual & mbu & 134 & 180 & 289 & 310 & 314 & 290 & 285 & 270 & 257 & 238 & 234 \\
\hline Domestic Use & mbu & 1,140 & 1,191 & 1,305 & 1,330 & 1,340 & 1,320 & 1,320 & 1,310 & 1,302 & 1,288 & 1,289 \\
\hline Exports & $\mathrm{mbu}$ & 910 & 1,050 & 940 & 934 & 952 & 970 & 987 & 1,006 & 1,021 & 1,045 & 1,052 \\
\hline Wheat Transportation & & & & & & & & & & & & \\
\hline Rail (Class I) & carloads & 315,600 & 346,740 & 343,798 & 346,369 & 350,695 & 351,056 & 354,087 & 355,852 & 357,247 & 359,505 & 360,807 \\
\hline Barge & bargeloads & 6,240 & 7,200 & 6,446 & 6,404 & 6,526 & 6,651 & 6,769 & 6,896 & 6,999 & 7,167 & 7,212 \\
\hline Truck & truckloads & 666,374 & 700,549 & 758,193 & 772,057 & 777,847 & 767,872 & 768,930 & 764,167 & 760,210 & 753,692 & 754,674 \\
\hline Sorghum Use & & 305 & 445 & 333 & 335 & 345 & 348 & 353 & 357 & 359 & 360 & 358 \\
\hline Feed \& residual & mbu & 110 & 180 & 123 & 120 & 125 & 125 & 125 & 125 & 125 & 120 & 120 \\
\hline Food, seed, \& industrial & mbu & 45 & 65 & 50 & 50 & 50 & 50 & 50 & 50 & 50 & 50 & 50 \\
\hline Domestic Use & $\mathrm{mbu}$ & 155 & 245 & 173 & 170 & 175 & 175 & 175 & 175 & 175 & 170 & 170 \\
\hline Exports & $\mathrm{mbu}$ & 150 & 200 & 161 & 165 & 170 & 173 & 178 & 182 & 184 & 190 & 188 \\
\hline $\begin{array}{l}\text { Sorghum Transportation } \\
\text { Rail (Class I) }\end{array}$ & & 25,000 & & & & & & & & & 30809 & 30.697 \\
\hline $\begin{array}{l}\text { Rail (Class I) } \\
\text { Barge }\end{array}$ & $\left|\begin{array}{l}\text { carloads } \\
\text { bargeloads }\end{array}\right|$ & $\begin{array}{r}25,000 \\
571\end{array}$ & $\begin{array}{r}34,429 \\
762\end{array}$ & $\begin{array}{r}26,986 \\
613\end{array}$ & $\begin{array}{r}27,535 \\
630\end{array}$ & $\begin{array}{r}28,303 \\
647\end{array}$ & $\begin{array}{r}28,771 \\
660\end{array}$ & $\begin{array}{r}29,360 \\
677\end{array}$ & $\begin{array}{r}29,925 \\
692\end{array}$ & $\begin{array}{r}30,275 \\
702\end{array}$ & $\begin{array}{r}30,899 \\
723\end{array}$ & $\begin{array}{r}30,697 \\
718\end{array}$ \\
\hline Truck & truckloads & 206,044 & 312,637 & 227,212 & 226,280 & 232,829 & 234,028 & 235,539 & 236,987 & 237,885 & 234,906 & 234,387 \\
\hline Barley Use & & 231 & 235 & 223 & 218 & 223 & 222 & 222 & 226 & 226 & 225 & 230 \\
\hline Feed \& residual & mbu & 55 & 60 & 50 & 45 & 50 & 50 & 50 & 55 & 55 & 55 & 60 \\
\hline Food, seed, \& industrial & $\mathrm{mbu}$ & 156 & 155 & 154 & 153 & 153 & 152 & 152 & 151 & 151 & 150 & 150 \\
\hline Domestic Use & $\mathrm{mbu}$ & 211 & 215 & 203 & 198 & 203 & 202 & 202 & 206 & 206 & 205 & 210 \\
\hline Exports & $\mathrm{mbu}$ & 20 & 20 & 20 & 20 & 20 & 20 & 20 & 20 & 20 & 20 & 20 \\
\hline Barley Transportation & & & & & & & & & & & & \\
\hline $\begin{array}{l}\text { Rail (Class I) } \\
\text { Barge }\end{array}$ & $\begin{array}{l}\text { carloads } \\
\text { bargeloads }\end{array}$ & 34,574 & 35,157 & 33,477 & 32,686 & 33,442 & 33,318 & 33,197 & 33,785 & 33,833 & 33,664 & 34,372 \\
\hline Truck & truckloads & 118,549 & 120,659 & 114,577 & 111,713 & 114,452 & 114,001 & 113,563 & 115,692 & 115,865 & 115,253 & 117,816 \\
\hline
\end{tabular}

*See Transportation Assumptions in the Summary of Transportation Requirements Table 6, Appendix I; USDA Long-term Projections Report, OCE-2007-1, February 2007.

Units: $\mathrm{mg}=$ million gallons; $\mathrm{mbu}=$ million bushels; mil. $\mathrm{s}$. tons=million short tons.

${ }^{1}$ USDA, World Agricultural Supply and Demand Estimates (WASDE), August 10, 2007.

${ }^{2}$ DDGS yield $=17.5 \mathrm{lbs} /$ bushel of corn used in ethanol production. 
Table 4: Summary of Transportation Requirements for the Baseline Scenario ${ }^{1}$

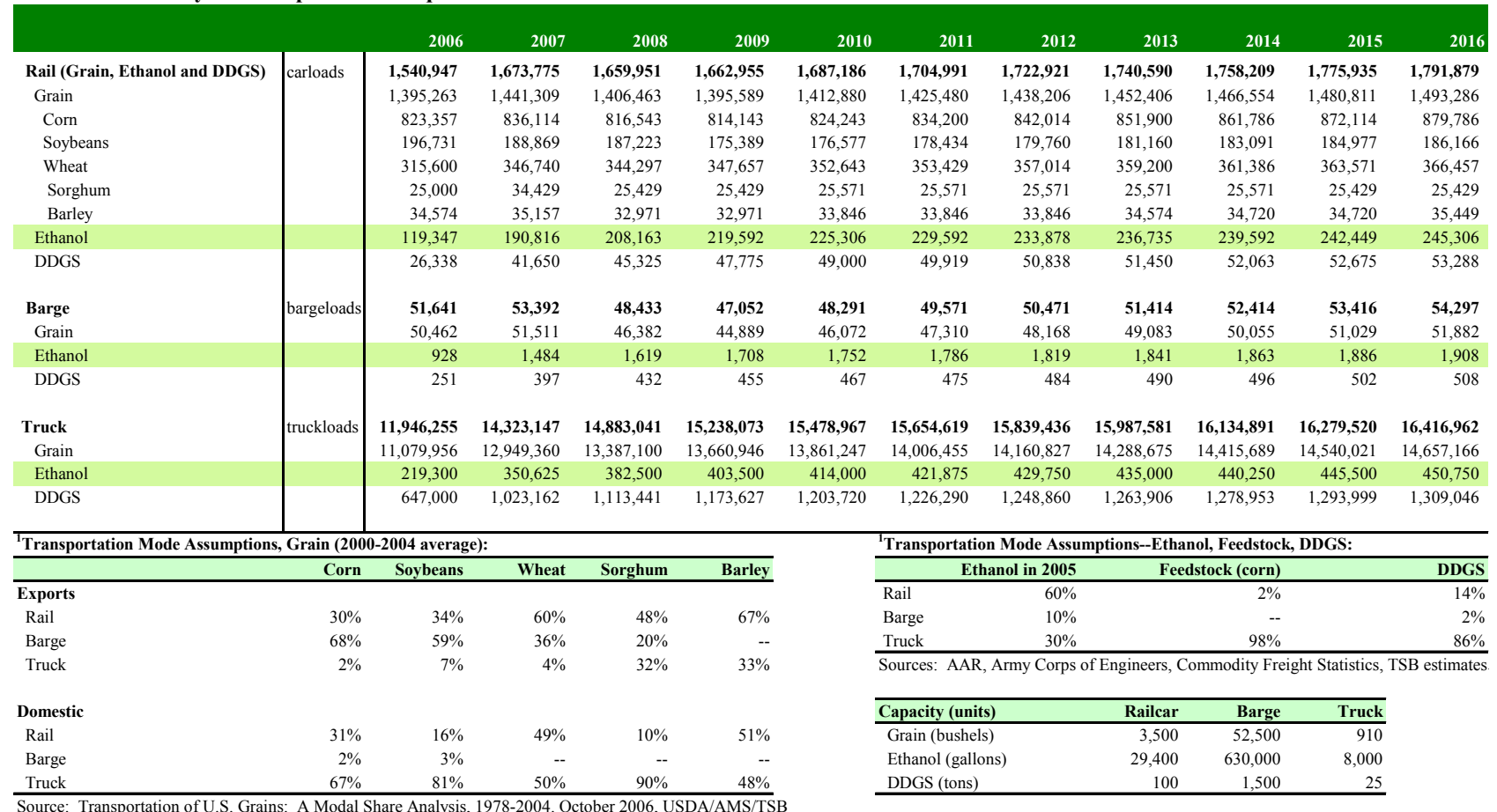

Table 5: Summary of Transportation Requirements for the 15-bgy Scenario ${ }^{1}$

\begin{tabular}{|c|c|c|c|c|c|c|c|c|c|c|c|c|}
\hline & & 2006 & 2007 & 2008 & 2009 & 2010 & 2011 & 2012 & 2013 & 2014 & 2015 & 2016 \\
\hline Rail Total & \multirow[t]{8}{*}{ carloads } & $1,539,290$ & $1,673,775$ & $1,647,285$ & $1,689,321$ & $1,737,297$ & $1,775,689$ & $1,812,039$ & $1,844,120$ & $1,874,845$ & $1,904,634$ & $1,932,850$ \\
\hline Grain & & $1,393,606$ & $1,441,309$ & $1,369,997$ & $1,390,367$ & $1,423,634$ & $1,449,578$ & $1,474,523$ & $1,496,764$ & $1,518,346$ & $1,539,687$ & $1,560,152$ \\
\hline Corn & & 823,357 & 836,114 & 783,462 & 812,189 & 839,021 & 862,219 & 882,866 & 900,662 & 918,501 & 935,696 & 952,012 \\
\hline Soybeans & & 195,074 & 188,869 & 186,105 & 174,425 & 174,901 & 176,790 & 177,455 & 178,989 & 180,338 & 182,444 & 183,100 \\
\hline Wheat & & 315,600 & 346,740 & 344,033 & 346,963 & 351,669 & 352,299 & 355,672 & 357,719 & 359,699 & 361,781 & 364,430 \\
\hline Sorghum & & 25,000 & 34,429 & 26,109 & 26,460 & 26,843 & 27,010 & 27,270 & 27,342 & 27,614 & 27,523 & 27,653 \\
\hline Barley & & 34,574 & 35,157 & 30,289 & 30,330 & 31,201 & 31,261 & 31,260 & 32,053 & 32,194 & 32,243 & 32,957 \\
\hline Ethanol & & 119,347 & 190,816 & 227,755 & 245,551 & 257,633 & 267,857 & 277,224 & 285,306 & 292,816 & 299,755 & 306,122 \\
\hline DDGS & & 26,338 & 41,650 & 49,533 & 53,403 & 56,030 & 58,254 & 60,291 & 62,049 & 63,682 & 65,191 & 66,576 \\
\hline Barge Total & \multirow[t]{4}{*}{ bargeloads } & 51,520 & 53,392 & 47,676 & 46,229 & 47,389 & 48,567 & 49,403 & 50,241 & 51,184 & 52,120 & 52,983 \\
\hline Grain & & 50,341 & 51,511 & 45,433 & 43,811 & 44,852 & 45,929 & 46,673 & 47,431 & 48,300 & 49,168 & 49,968 \\
\hline Ethanol & & 928 & 1,484 & 1,771 & 1,910 & 2,004 & 2,083 & 2,156 & 2,219 & 2,277 & 2,331 & 2,381 \\
\hline DDGS & & 251 & 397 & 472 & 509 & 534 & 555 & 574 & 591 & 606 & 621 & 634 \\
\hline Truck Total & \multirow[t]{4}{*}{ truckloads } & $11,932,134$ & $14,323,147$ & $15,240,308$ & $16,074,384$ & $16,661,012$ & $17,145,105$ & $17,602,654$ & $17,992,432$ & $18,357,855$ & $18,698,300$ & $19,020,350$ \\
\hline Grain & & $11,065,835$ & $12,949,360$ & $13,605,004$ & $14,311,304$ & $14,811,184$ & $15,221,865$ & $15,612,155$ & $15,943,906$ & $16,255,405$ & $16,546,029$ & $16,822,361$ \\
\hline Ethanol & & 219,300 & 350,625 & 418,500 & 451,200 & 473,400 & 492,188 & 509,400 & 524,250 & 538,050 & 550,800 & 562,500 \\
\hline DDGS & & 647,000 & $1,023,162$ & $1,216,804$ & $1,311,880$ & $1,376,428$ & $1,431,053$ & $1,481,099$ & $1,524,276$ & $1,564,400$ & $1,601,471$ & $1,635,489$ \\
\hline \multicolumn{13}{|c|}{ Table 6: Summary of Transportation Requirements for the 20-bgy Scenario ${ }^{1}$. } \\
\hline & & 2006 & 2007 & 2008 & 2009 & 2010 & 2011 & 2012 & 2013 & 2014 & 2015 & 2016 \\
\hline Rail Total Carloads & carloads & $1,539,290$ & $1,673,775$ & $1,673,900$ & $1,679,339$ & $1,708,312$ & $1,730,516$ & $1,753,544$ & $1,772,071$ & $1,800,410$ & $1,808,849$ & $1,854,355$ \\
\hline Grain & & $1,393,606$ & $1,441,309$ & $1,371,766$ & $1,343,115$ & $1,344,955$ & $1,342,289$ & $1,341,488$ & $1,337,753$ & $1,344,525$ & $1,332,093$ & $1,357,424$ \\
\hline Corn & & 823,357 & 836,114 & 782,440 & 763,545 & 759,952 & 755,166 & 751,099 & 743,426 & 748,687 & 729,983 & 758,564 \\
\hline Soybeans & & 195,074 & 188,869 & 185,064 & 172,980 & 172,563 & 173,978 & 173,745 & 174,766 & 174,483 & 178,041 & 172,984 \\
\hline Wheat & & 315,600 & 346,740 & 343,798 & 346,369 & 350,695 & 351,056 & 354,087 & 355,852 & 357,247 & 359,505 & 360,807 \\
\hline Sorghum & & 25,000 & 34,429 & 26,986 & 27,535 & 28,303 & 28,771 & 29,360 & 29,925 & 30,275 & 30,899 & 30,697 \\
\hline Barley & & 34,574 & 35,157 & 33,477 & 32,686 & 33,442 & 33,318 & 33,197 & 33,785 & 33,833 & 33,664 & 34,372 \\
\hline Ethanol & & 119,347 & 190,816 & 248,163 & 276,163 & 298,449 & 318,878 & 338,449 & 356,735 & 374,449 & 391,592 & 408,163 \\
\hline DDGS & & 26,338 & 41,650 & 53,971 & 60,061 & 64,907 & 69,350 & 73,607 & 77,583 & 81,436 & 85,164 & 88,768 \\
\hline Barge Total Bargeloads & bargeloads & 51,520 & 53,392 & 47,080 & 45,122 & 45,873 & 46,628 & 47,079 & 47,272 & 48,328 & 47,862 & 50,293 \\
\hline Grain & & 50,341 & 51,511 & 44,635 & 42,402 & 42,933 & 43,488 & 43,746 & 43,758 & 44,640 & 44,006 & 46,273 \\
\hline Ethanol & & 928 & 1,484 & 1,930 & 2,148 & 2,321 & 2,480 & 2,632 & 2,775 & 2,912 & 3,046 & 3,175 \\
\hline DDGS & & 251 & 397 & 514 & 572 & 618 & 660 & 701 & 739 & 776 & 811 & 845 \\
\hline Truck Total Truckloads & truckloads & $11,932,134$ & $14,323,147$ & $15,909,526$ & $16,674,227$ & $17,332,492$ & $17,915,410$ & $18,491,119$ & $19,014,100$ & $19,565,318$ & $20,011,768$ & $20,610,841$ \\
\hline Grain & & $11,065,835$ & $12,949,360$ & $14,127,689$ & $14,691,348$ & $15,189,599$ & $15,625,838$ & $16,061,022$ & $16,452,710$ & $16,876,738$ & $17,200,100$ & $17,680,189$ \\
\hline Ethanol & & 219,300 & 350,625 & 456,000 & 507,450 & 548,400 & 585,938 & 621,900 & 655,500 & 688,050 & 719,550 & 750,000 \\
\hline DDGS & & 647,000 & $1,023,162$ & $1,325,837$ & $1,475,429$ & $1,594,493$ & $1,703,635$ & $1,808,197$ & $1,905,890$ & $2,000,530$ & $2,092,118$ & $2,180,652$ \\
\hline
\end{tabular}




\section{Appendix II - Illustrations}

\section{Rail and Truck Ethanol Distribution System}

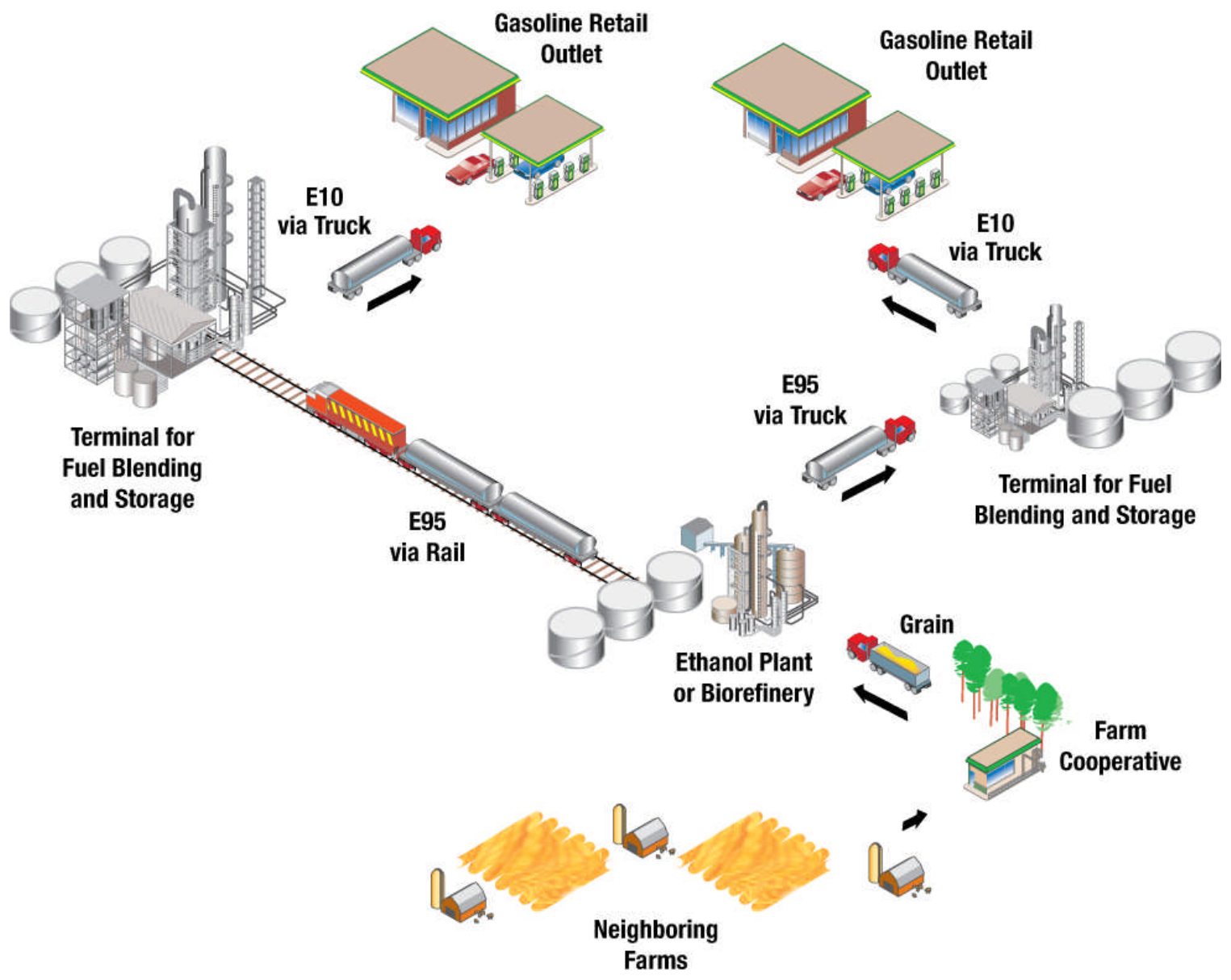

Source: National Bioenergy Center, National Renewable Energy Laboratory; E95 is Fuel Ethanol (200-proof alcohol denatured with 5 percent natural gasoline.) 


\section{Flex-Fuel Vehicles in the United States}

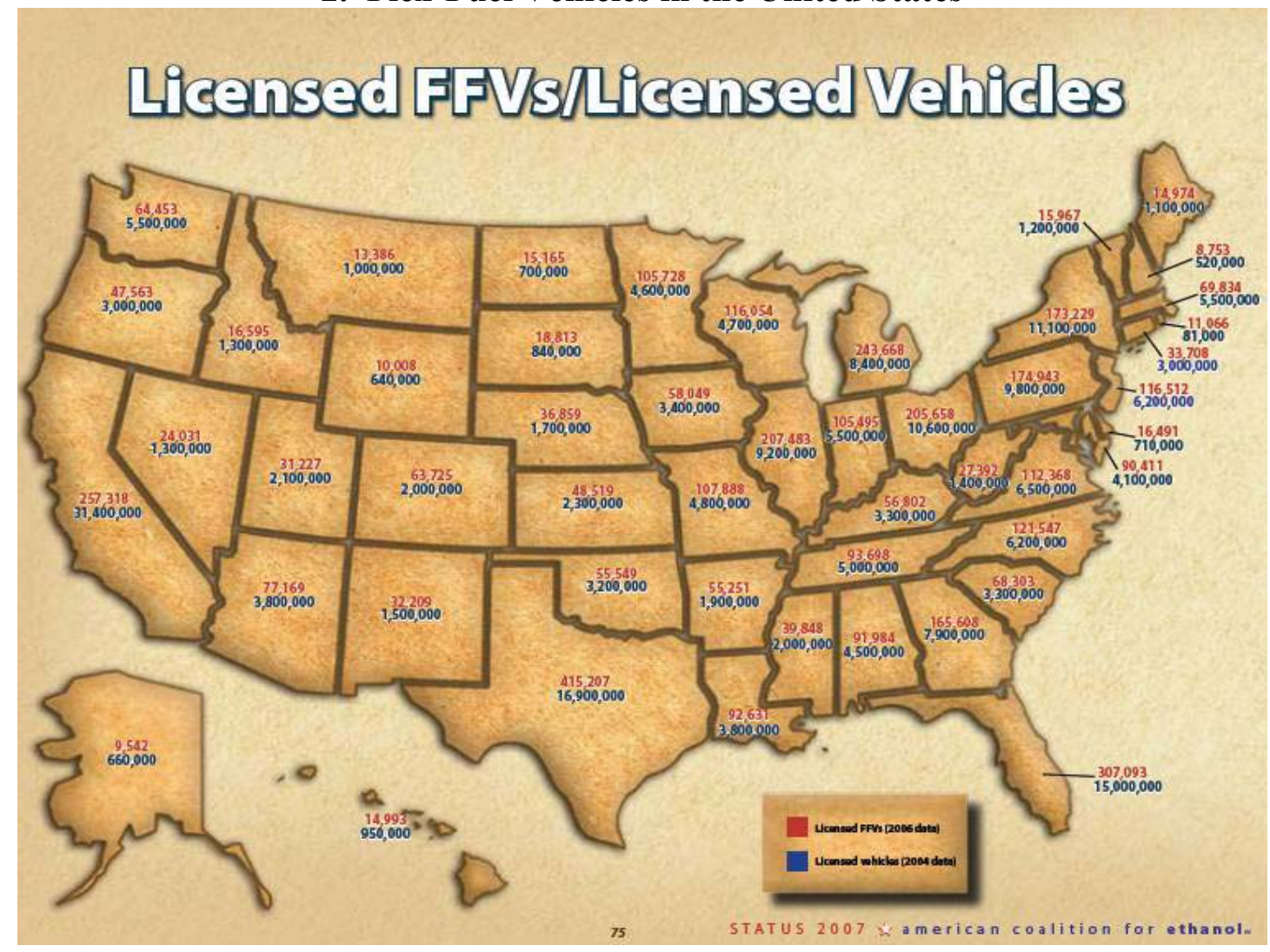

E85 Stations by State, as of July 31, 2007

\begin{tabular}{|l|c|l|c|}
\hline \multicolumn{1}{|c|}{ STATE } & E85 & \multicolumn{1}{c|}{ STATE } & E85 \\
\hline Alabama & 2 & Mississippi & 1 \\
\hline Alaska & 0 & Missouri & 59 \\
\hline Arizona & 9 & New Jersey & 0 \\
\hline Arkansas & 4 & New Mexico & 6 \\
\hline California & 4 & New York & 6 \\
\hline Colorado & 26 & North Carolina & 9 \\
\hline Connecticut & 0 & North Dakota & 24 \\
\hline Delaware & 1 & Ohio & 34 \\
\hline DC & 3 & Oklahoma & 1 \\
\hline Florida & 10 & Oregon & 5 \\
\hline Georgia & 9 & Pennsylvania & 11 \\
\hline Hawaii & 0 & Rhode Island & 0 \\
\hline Idaho & 3 & South Carolina & 46 \\
\hline IIlinois & 146 & South Dakota & 58 \\
\hline Indiana & 84 & Tennessee & 9 \\
\hline Iowa & 68 & Texas & 29 \\
\hline Kansas & 15 & Utah & 4 \\
\hline Kentucky & 7 & Vermont & 0 \\
\hline Louisiana & 0 & Virginia & 5 \\
\hline Maine & 0 & Washington & 6 \\
\hline Maryland & 7 & West Virginia & 2 \\
\hline Massachusetts & 0 & Wisconsin & 60 \\
\hline Michigan & 44 & Wyoming & 6 \\
\hline Minnesota & 306 & U.S. Total & 1166 \\
\hline SOure: Stan & \\
\hline
\end{tabular}

Source: State data as of July 31, 2007:

http://www.eere.energy.gov/afdc/infrastructure/station_maps.h 


\section{Freight Specs by Mode}

a) Rail Tank Car - typically 30,000 gallons, AAR type T108.

Example:

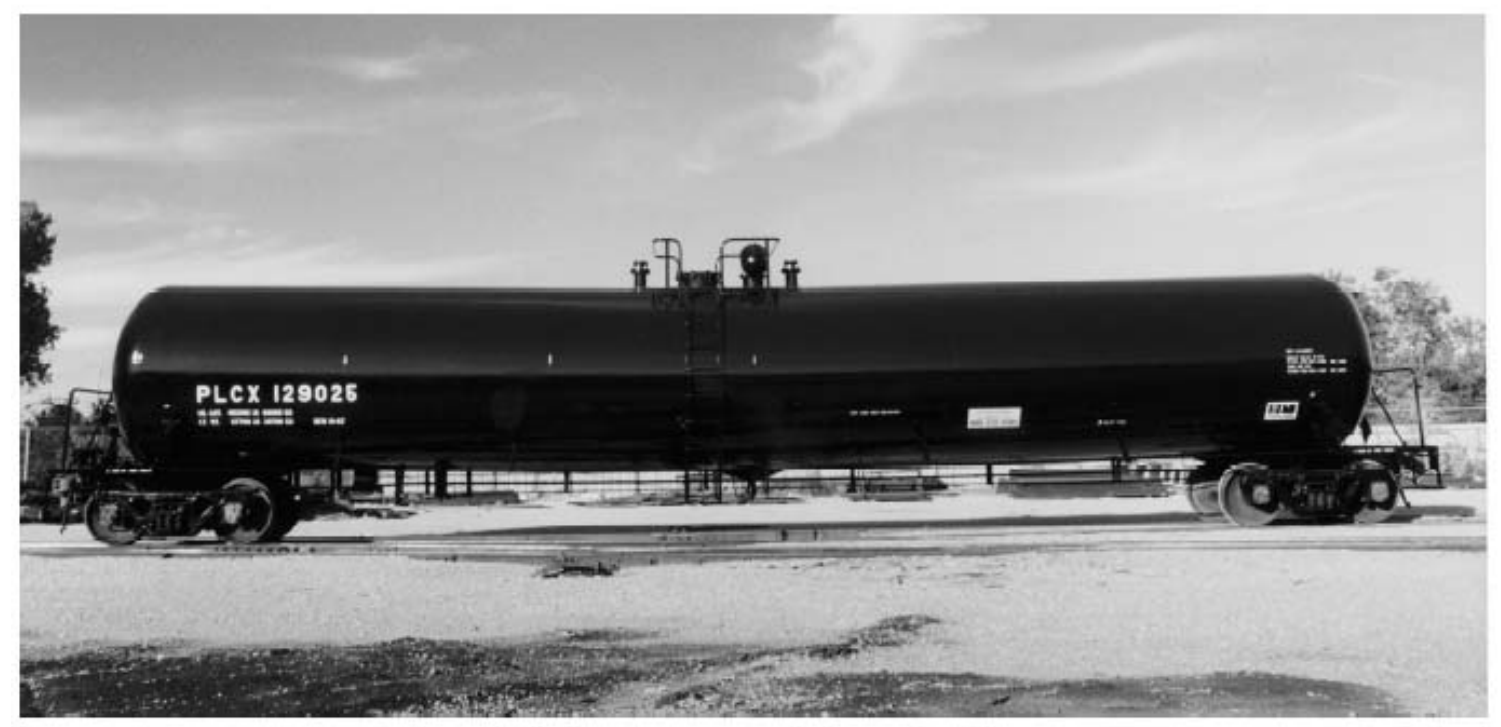

PLCX 129025 is a non-insulated tank without coils. This is the type of tank that usually carries alcohol, methanol and related products. This has a 29,815 gallon capacity. It was built in October 1987 by Trinity Industries (File \# 8725). DOT class 111A100W1. AAR car type code T108. External length 67'11".

Source: Freight Cars Journal

b) Tanker Truck - 8,000 gallons

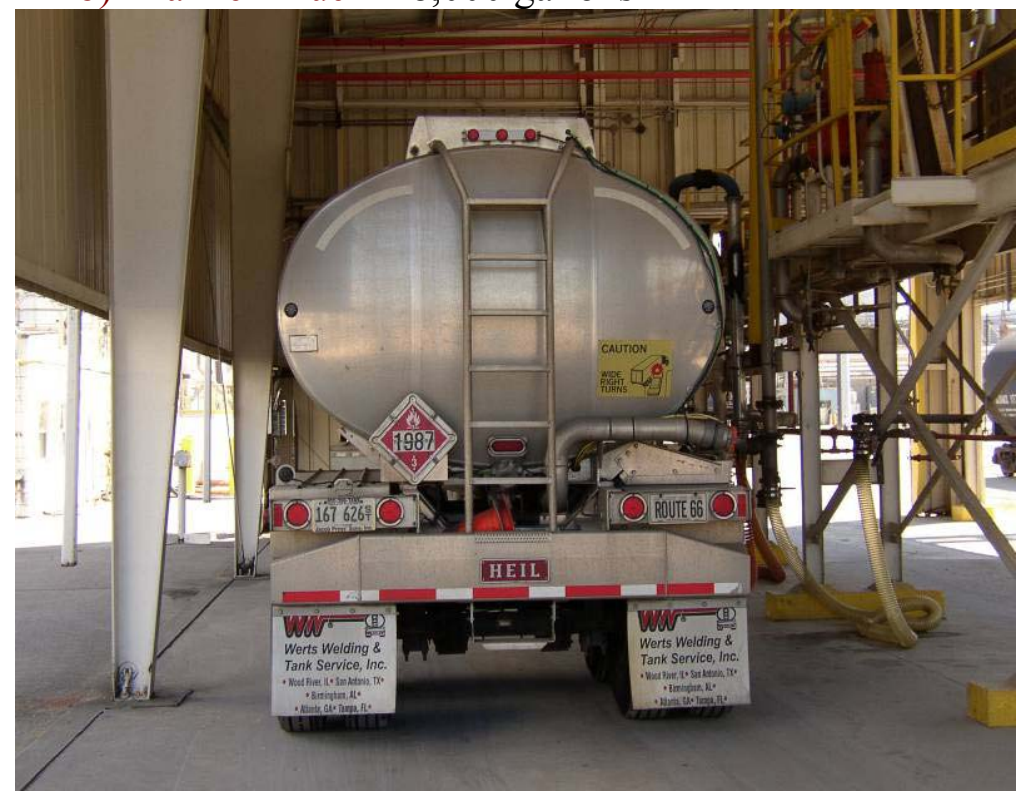


c) Tank barge - 1 million gallons $(23,900$ barrels $)$

\section{Inland Liquid Cargo Tank Barge}

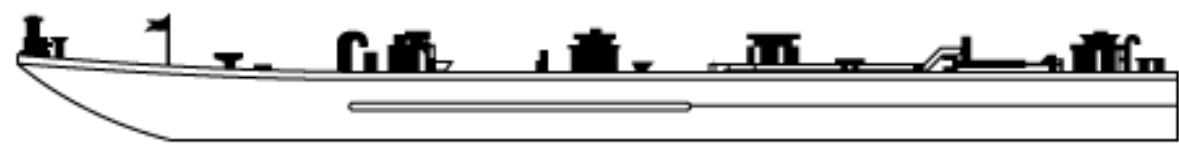

Kirby Corp. - 2-barge tow capacity 60,000 barrels, 2.52 million gallons, 1 barge -1.26 mill. gal. http://www.kirbycorp.com/corp/history.cfm

\section{d) 5161-Cubic Foot Covered Hopper}

This 286,000 lb. gross rail load covered hopper has standard 24-inch continuous trough hatch and standard 30-inch by 30-inch discharge outlets. A wide assortment of options is available including a variety of hatch and gate configurations as well as interior lining if required.

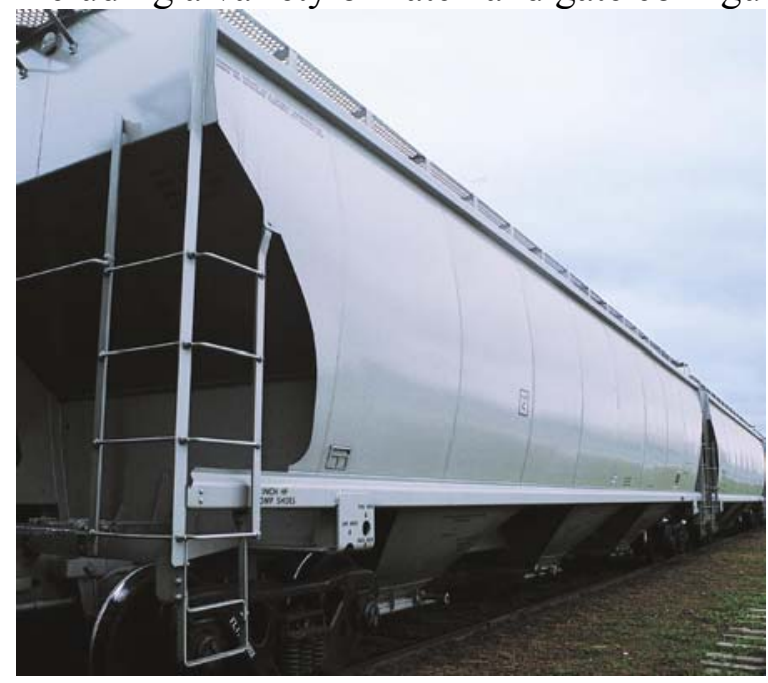

http://www.trinityrail.com/railcars/hopper/pdfs/hopper 5161.pdf 


\section{4. a. Ethanol Cargo Capacity Comparison}
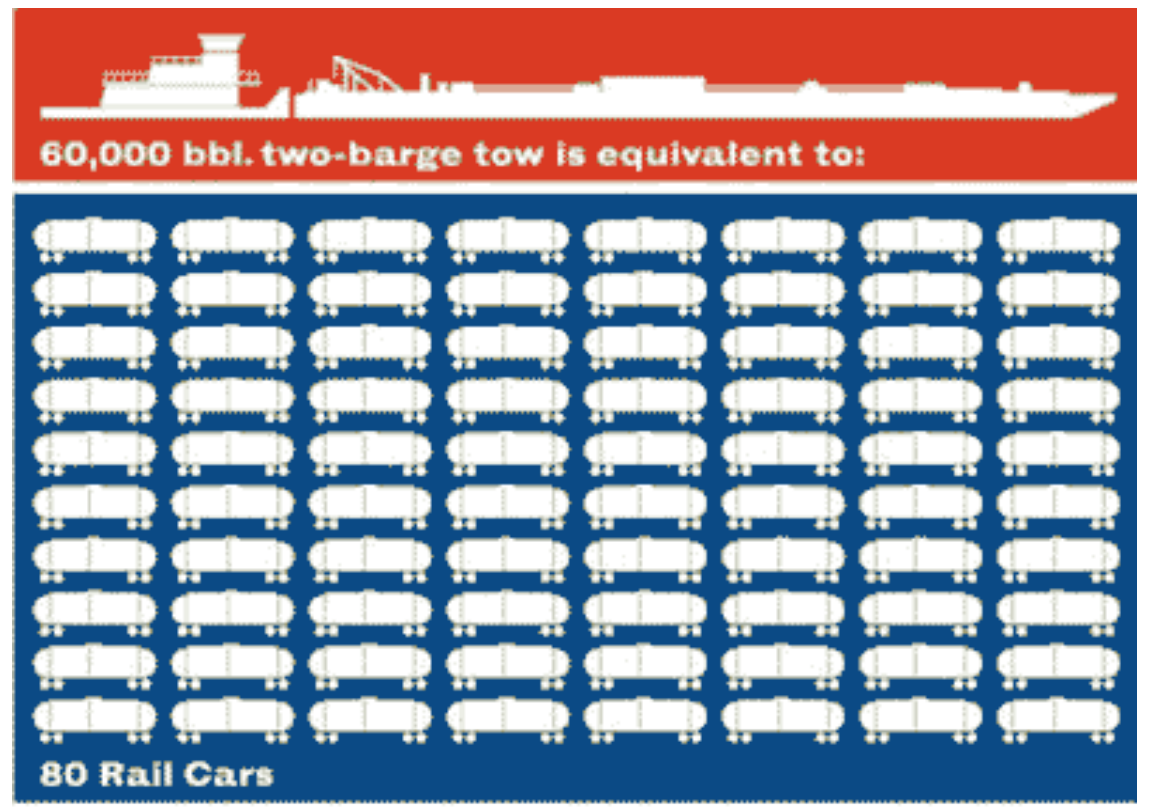

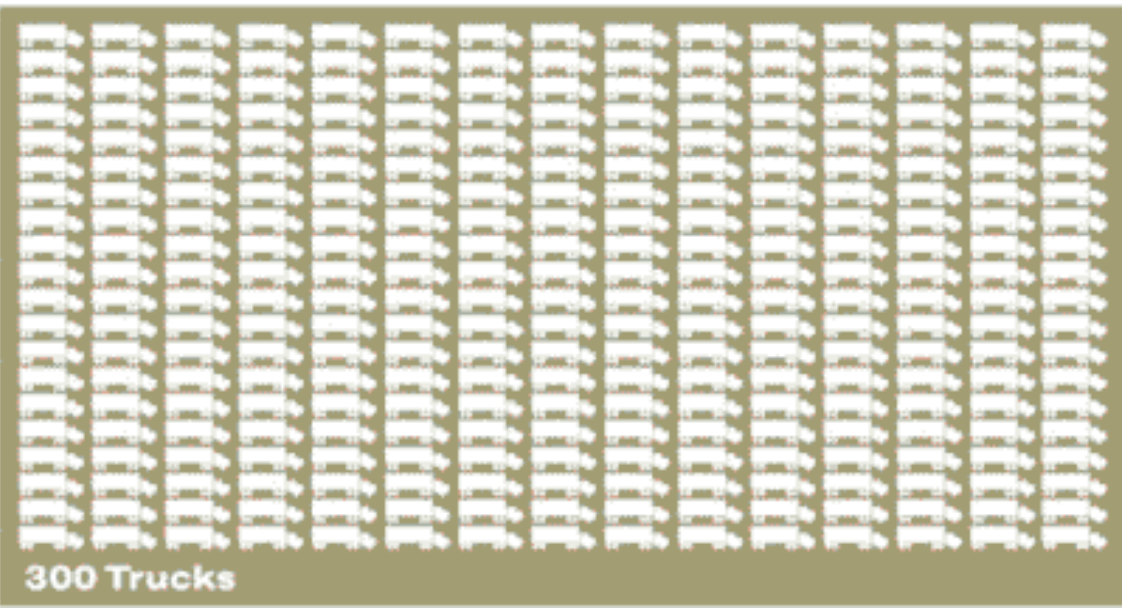




\section{4. b. Grain Cargo Capacity Comparison}

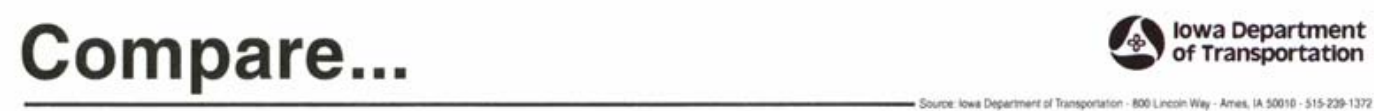

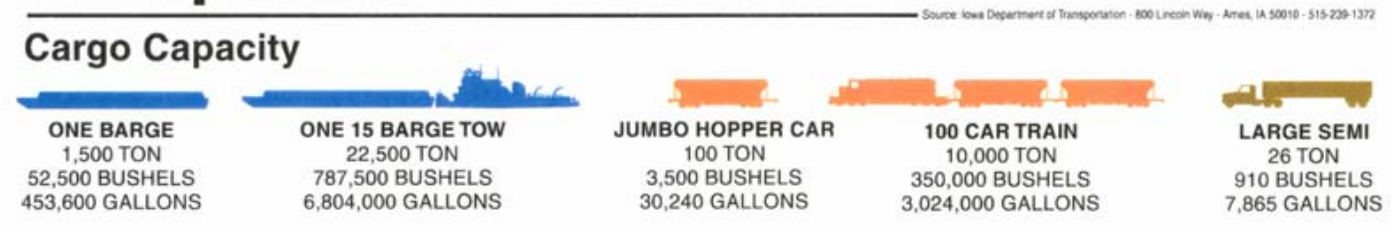

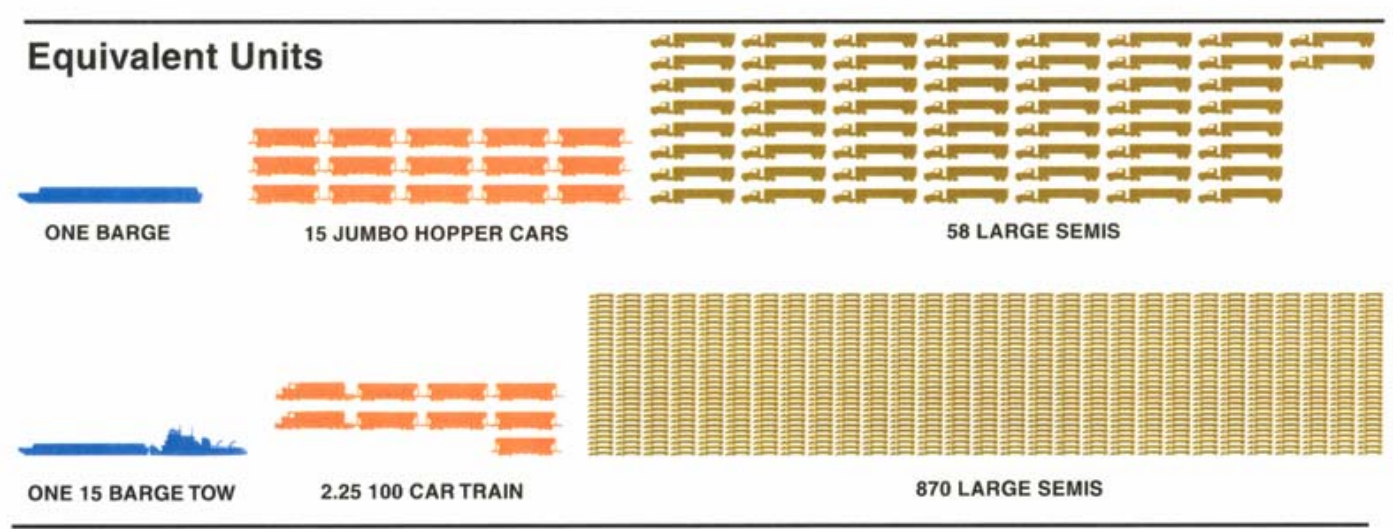

\section{Equivalent Lengths

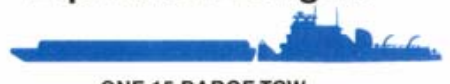

ONE 15 BARGE TOW

.25 MILE

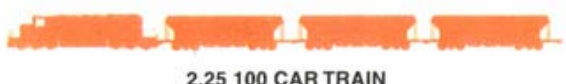

2.25100 CAR TRAIN

2.75 MILES

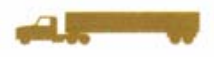

870 LARGE SEMIS

11.5 MILES

(BUMPER TO BUMPER) 


\section{Resources and Links}

Grain Transportation Report - Weekly developments affecting the transport of grain in the domestic and international marketplace. www.ams.usda.gov/tmdtsb/grain/

National Weekly Ethanol Summary - Weekly spot prices for ethanol and distillers' grains. http://www.ams.usda.gov/lsmnpubs/PDF_Weekly/Ethanol.pdf(PDF)

Market News Reports Portal - Searchable database of prices for various commodities at many locations. http://marketnews.usda.gov/portal/lg

USDA Baseline Projections - Long-term projections of many commodities. http://www.usda.gov/oce/commodity/ag baseline.htm

USDA Economic Research Service Briefing Room - In-depth analyses of economic issues in agriculture. http://www.ers.usda.gov/Briefing/

USDA Economic Research Service - Ethanol Expansion in the United States. How Will the Agricultural Sector Adjust? May 2007.

http://www.ers.usda.gov/Publications/FDS/2007/05May/FDS07D01/fds07D01.pdf(PDF)

Feed Grains Backgrounder - An overview of the current and projected situation for U.S. feed grains. http://www.ers.usda.gov/Publications/FDS/2007/03Mar/FDS07C01/

Feed Grains Database - A queriable database that contains monthly, quarterly, and annual data on prices, supply, and use of corn and other feed grains, including data published in the monthly Feed Outlook and the annual Feed Yearbook reports. www.ers.usda.gov/data/feedgrains/

Ethanol Facts: Food vs. Fuel - the Renewable Fuels Association provides a perspective on the issue. http://www.ethanolrfa.org/resource/facts/food/

Review of Transportation Issues and Comparison of Infrastructure Costs for a Renewable Fuels Standard - Report from DOE's Energy Information Administration. http://www.eia.doe.gov/oiaf/servicerpt/fuel/rfs.html

Alternative Fuels Data Center - A portal to information about alternative fuels and vehicles from DOE. http://www.eere.energy.gov/afdc/

Iowa State University CARD - Locations of ethanol plants in the United States http://www.card.iastate.edu/research/bio/tools/ethanol.aspx

Potential Infrastructure Constraints on Ethanol Production in Iowa - From Iowa State. http://www.extension.iastate.edu/ag/GinderPresent.indd.pdf(PDF)

Railroads: BNSF, www.bnsf.com;

CSX, www.csX.com;

$\mathrm{CN}$, http://www.cn.ca/productsservices/grain/resource centre/Ethanol/en ethanol.shtml

Norfolk Southern Corporation,

http://www.nscorp.com/nscportal/nscorp/Customers/Industrial\%20Products/Agriculture/

Union Pacific, http://www.uprr.com/customers/ag-prod/ethanol.shtml 


\section{CONTACT INFORMATION}

\author{
Author \\ Marina R. Denicoff \\ Contributors \\ Johnny Hill \\ Nicholas Marathon \\ Brian McGregor \\ Marvin Prater \\ April Taylor
}

marina.denicoff@usda.gov

(202) 720-8264

johnny.hill@usda.gov

nick.marathon@usda.gov

brian.mcgregor@usda.gov

marvin.prater@usda.gov

april.taylor@usda.gov
(202) 720-4211

(202) 690-0331

(202) 690-1319

(202) 690-6290

(202) 295-7374

\section{Acknowledgments}

The author thanks Hosein Shapouri and Harry Baumes, USDA, Office of Energy Policy and New Uses; Paul Westcott, Economic Research Service; and Jerry Norton, USDA, World Agricultural Outlook Board for providing substantive comments during the review process.

\section{Preferred Citation}

U.S. Department of Agriculture, Agricultural Marketing Service. Ethanol Transportation Backgrounder, September 2007. Web. <http://dx.doi.org/10.9752/TS029.09-2007> 